Article

\title{
Assessing the Market for Solar Photovoltaic (PV) Microgrids in Malawi
}

\author{
Aran Eales *, Alfred Alsop, Damien Frame, Scott Strachan, Stuart Galloway \\ University of Strathclyde, 16 Richmond St, Glasgow G1 1XQ, UK \\ * Correspondence: Aran Eales, Email: aran.eales@strath.ac.uk; \\ Tel.: +44-141-444-7266.
}

\begin{abstract}
Access to energy is widely acknowledged as an enabler for development, and a lack of energy is a barrier to economic empowerment. Currently just $12 \%$ of the Malawian population have access to the national electricity grid, with rural electrification at only 5.3\%. Solar photovoltaic (PV) microgrids offer increased access levels over pico-solar systems and solarhome systems, and are a successful rural electrification method in many areas of Africa. This paper addresses the research question of: "what is the market potential for solar microgrids in Malawi?” through a multidisciplinary methodology and outlines necessary steps to overcome the key risks and barriers for implementation nationally. Case studies of existing initiatives in Kenya and Rwanda have been used to inform a system and business design appropriate to Malawi. The market potential of PV microgrids in Malawi has been identified and quantified through a novel approach combining microgrid optimisation software HOMERPro with Geographic Information Systems tools. The methodology also includes an energy ecosystem mapping exercise to identify and frame influencing parameters affecting microgrid implementation nationally. The findings show that solar microgrids are cost competitive with diesel microgrids in all locations in Malawi, although the addition of dispatchable diesel generation may provide economic benefits in larger, more urban systems. To implement solar microgrids would cost approximately $\$ 210$ per person and average operational expenses of $\$ 17$ per person per year. It was determined that $42 \%$ of Malawians may be most cost effectively served by existing infrastructure, $37 \%$ would be best served by microgrids and $21 \%$ would be best served by solar-home systems.
\end{abstract}

\section{G Open Access}

Received: 07 November 2019 Accepted: 24 December 2019 Published: 07 January 2020

Copyright (c) 2020 by the author(s). Licensee Hapres, London, United Kingdom. This is an open access article distributed under the terms and conditions of Creative Commons Attribution $\underline{4.0 \text { International License. }}$
KEYWORDS: market assessment; solar microgrids; Malawi; Geographic Information Systems; techno-economic modelling

\section{ABBREVIATIONS}

CAPEX, Capital Expenditure; CEM, Community Energy Malawi; COE, Cost of Energy; ESCOM, CPE, Customer Premises Equipment: Energy Supply Company; GDP, Gross Domestic Product; GIS, Geographic Information 
Systems; HH, Household; MAREP, Malawi Rural Electrification Programme; MEGA, Mulanje Electricity Generating Agency; MERA, Malawi Energy Regulatory Authority; NEP, National Energy Policy; OPEX, Operational Expenditure; PAYG, Pay As You Go; PBK, Portable Battery Kits; PSP, Pico Solar System; PUE, Productive Uses of Energy; PV, Photovoltaic; REF, Rural Electrification Fund; RISE, Regulatory Indicators for Sustainable Energy; SDGs, Sustainable Development Goals; SE4All, Sustainable Energy for All; SHS, Solar Home System; SoNG, Solar NanoGrid; VEC, Village Energy Committee

\section{INTRODUCTION}

Malawi is one of the poorest countries in the world, with an economy highly dependent on agriculture. In 2018, Malawi had a population of 18.14 million and a Gross Domestic Product (GDP) per Capita of USD 389 [1]. With agriculture accounting for $30 \%$ of Malawi's economy, the country faces development challenges including vulnerability to external shocks such as climate change and health, rapid population growth and environmental degradation [2].

Access to energy is an enabler for development and a lack of energy is a barrier to economic empowerment and poverty eradication. This has been globally recognised with the UN Secretary General's "Sustainable Energy for All” (SE4All) initiative [3] and Sustainable Development Goal (SDG) 7, with the objective of achieving universal access to clean, affordable and reliable energy [4]. Malawi's average annual electricity use per capita is $85 \mathrm{kWh}$ compared with an average of $169 \mathrm{kWh}$ in eastern Africa [5], and while the national grid serves $12 \%$ of the population in Malawi, only 5.3\% of the rural population are grid-connected [1,3].

A new National Energy Policy (NEP) (2018) [6] and Renewable Energy Strategy [7] were launched in 2018 in parallel with Malawi's "Sustainable Energy for All” Action Agenda. These jointly outline strategies for increased deployment of renewable energy generation and the use of decentralised energy systems to support increased electricity access for underserved rural populations. Policy targets include access to electricity for every citizen in the country by the year 2030, and ensuring $100 \%$ of schools and health centres have access to modern, sustainable energy solutions by 2025 [6]. Given that $54 \%$ of Malawians live more than $5 \mathrm{~km}$ away from the national grid in peri-urban and rural areas [8], providing energy access for the 9 million people living there will most likely be achieved via more affordable and expeditious off-grid electrification. It is expected that microgrids will play a significant role in implementing this policy and meeting the strategic objectives of increasing electricity access, evidenced with NEP targets of establishing at least 50 renewable energy microgrids by 2025 [6].

Within this context, development of planning and decision making frameworks that can assess the social, economic and technical viability of different rural electrification strategies are essential for effective energy 
access investments in Malawi. This paper addresses the research question of: "what is the market potential for solar microgrids in Malawi?" and outlines necessary steps to overcome the key risks and barriers for implementation nationally. The study has developed a methodology for assessing the market for solar microgrids in sub-Saharan contexts, assessing the viability of the technology for different deployment contexts and establishing appropriate measures required to make these systems technically, economically and socially viable, and sustainable within these contexts. The methodology has identified key risks and barriers associated with the implementation of the technology in SSA, and determined mitigation measures where appropriate.

The study has then applied the methodology in a Malawian context to identify the key risks and barriers associated with the implementation of this technology here, determine its viability, and establish appropriate risk mitigation measures. The market assessment aims to determine if solar microgrids have the potential to increase sustainable energy access in Malawi, and thereby contribute to poverty reduction. The assessment also identifies locations and circumstances where solar microgrids appear most viable, and what specific measures are required to mitigate any deployment risks and ensure sustainability of the technology. Section "SOLAR MICROGRIDS IN MALAWI" builds on the context outlined above justifying solar microgrids as an effective method for rural electrification and their potential use in Malawi, while Section "SOLAR MICROGRID MARKET ASSESSMENT METHODOLOGY" outlines the three stage methodology of the study. Section "RESULTS" highlights the key results and a discussion section follows in Section "DISCUSSION", before presenting the research conclusions in the last section.

\section{SOLAR MICROGRIDS IN MALAWI}

\section{Solar Microgrids as an Electrification Solution}

In recent years, a clear increase in the successes of Solar Home Systems (SHS) has been noted globally [9], with a wide body of literature documenting the successes and limitations of different business models in facilitating the growth in the sector. Similarly, the impacts of access to electricity via SHS is being reported on issues as diverse as health, education, security, communications and income [10,11]. However, despite developmental gains such as lighting for study and removal of air pollution and lower cost from kerosene replacement, opportunities for income generation are less clear or small [12,13], and the upfront costs of SHS are still too high for many of Africa's poorest. Chattopadhyay et al. [14] recommends that they should primarily be viewed as a short-term solution, which should be continually scrutinized, reviewed, updated, and replaced with options that provide lower-cost, higher quality power as they become available. Solar microgrids provide an opportunity for addressing some of the limitations of SHS, where basic electricity needs of 
the households are met, with potential for additional small scale agricultural or industrial productive uses of energy.

A nanogrid, microgrid or minigrid is a term used to describe a network consisting of a group of interconnected loads and distributed energy resources within clearly defined electrical boundaries that acts as a single controllable entity with respect to the grid [15]. Several definitions for microgrids exists; however, this paper follows IRENA guidelines and classifies a solar microgrid as a solar PV generation and supply system with maximum capacity of $100 \mathrm{~kW}$, having capabilities of managing local energy supply [16]. Microgrids have the potential to address SDG 7 by enhancing socio-economic wellbeing through improved quality of life, access to public services, job creation and entrepreneurship opportunities and industrialisation enabled by access to energy [5].

The deployment of microgrids utilising solar PV generation capacity is on the rise globally, mainly due to decreasing costs of solar PV modules, battery storage and ancillary components, and offers a low carbon cost competitive solution to rural electrification in areas unlikely to receive a grid connection in the near future [17]. The IEA estimates microgrids could serve 212 million people by 2030 [17], and given the approximately $80 \%$ decline in solar PV module prices since the end of 2009, coupled with high levels of solar resource throughout Africa, there is huge untapped economic potential for this highly modular and scalable technology to address the energy access targets of 2030 [18].

Table 1 is an indicative comparison between solar microgrids to other technologies in terms of costs, area reached, distributions channels, maintenance and durability. Dry cell battery powered torches are omitted from the table, although they are prevalent as a lighting source in Malawi. Advantages of solar microgrids compared to solar home systems are outlined in Table 2. The information in both tables is adapted from [19] and [20] respectively to provide context and not used in later modelling stages of the paper.

SE4All defines common types of electricity access in Sub-Saharan Africa, according to standardised tiers of electricity access according to affordability, duration of supply, quality of supply, safety and legality [21]. The majority of Malawian people have access to Tier 1 energy (through pico-solar products) [22], however the poor quality and standard of the products available remains an issue. $12 \%$ of the population have access to Tier 4 grid electricity, when taking into consideration the unreliable nature of the grid supply and the routine outages suffered by customers. 
Table 1. Comparing solar microgrids to other technologies (adapted from [19]).

\begin{tabular}{|c|c|c|c|c|c|c|c|}
\hline Technology & $\begin{array}{l}\text { Power of } \\
\text { system }\end{array}$ & $\begin{array}{l}\text { Area reached } \\
\text { by one system }\end{array}$ & Cost of energy & $\begin{array}{l}\text { Distribution } \\
\text { channel/ } \\
\text { Provider }\end{array}$ & $\begin{array}{l}\text { Services } \\
\text { provided }\end{array}$ & $\begin{array}{l}\text { Maintenance (Difficulty } \\
\text { and responsible party) }\end{array}$ & Life expectance of product \\
\hline Kerosene (Tier 0) & N/A & $1 \mathrm{room}$ & $\$ 20-45$ (per kWh equivalent) & Local Supplier & Light & Easy: Owner & $0.5 \mathrm{~L}$ per night \\
\hline $\begin{array}{l}\text { Solar lanterns } \\
\text { (Tier 1) }\end{array}$ & $\sim 10 \mathrm{~W}$ & 1 room & $\$ 2$ for lantern unit & Retail stores & Light & Easy: Owner & $3-5$ years \\
\hline $\begin{array}{l}\text { Solar Home } \\
\text { Systems (Tier 2) }\end{array}$ & $10-200 \mathrm{~W}$ & 1 household & $\$ 0.6+$ per $\mathrm{kWh}$ & $\begin{array}{l}\text { Retail stores and } \\
\text { Enterprises }\end{array}$ & Lights, Charging & $\begin{array}{l}\text { Moderate: owner or } \\
\text { provider of product }\end{array}$ & $\begin{array}{l}\text { Batteries } 3-5 \text { years, PV panels } \\
20-25 \text { years }\end{array}$ \\
\hline $\begin{array}{l}\text { Solar microgrids } \\
\text { (Tier 3-4) }\end{array}$ & $\begin{array}{l}100 \mathrm{~W}+\text { per } \\
\text { village }\end{array}$ & $\begin{array}{l}1 \text { village ( } 50- \\
500 \text { houses) }\end{array}$ & $\begin{array}{l}\$ 0.2+\text { per } \mathrm{kWh} \text { if not asked to } \\
\text { contribute to up-front costs }\end{array}$ & $\begin{array}{l}\text { Enterprises and } \\
\text { other organisations }\end{array}$ & $\begin{array}{l}\text { Light, Charging, } \\
\text { Outlets, Some } \\
\text { Industry }\end{array}$ & $\begin{array}{l}\text { Difficult: Owner or } \\
\text { technician }\end{array}$ & $\begin{array}{l}\text { Batteries } 5 \text { years, PV panels } 20- \\
25 \text { years }\end{array}$ \\
\hline $\begin{array}{l}\text { National Grid } \\
\text { (Tier 4-5) }\end{array}$ & $\begin{array}{l}100-2200 \mathrm{~W} \\
\text { per home }\end{array}$ & $\mathrm{N} / \mathrm{A}$ & $\begin{array}{l}\$ 0.1-0.2^{1} \text { (per kWh, tariff } \\
\text { schemes vary by country) }\end{array}$ & $\begin{array}{l}\text { Government or } \\
\text { national utility }\end{array}$ & $\begin{array}{l}\text { Light, outlets, } \\
\text { industry }\end{array}$ & $\begin{array}{l}\text { Most difficult: Government } \\
\text { or national Utility }\end{array}$ & $\begin{array}{l}\text { Indefinite (persistent } \\
\text { replacement and upgrades) }\end{array}$ \\
\hline
\end{tabular}

${ }^{1}$ subsidised cost to the customer.

Table 2. Advantages and shortcomings of stand-alone and microgrid renewable energy systems [20].

\begin{tabular}{|c|c|c|}
\hline Solar technology & Advantages & Shortcomings \\
\hline $\begin{array}{l}\text { Stand-alone RE systems (Solar } \\
\text { lanterns and Solar Home Systems) }\end{array}$ & $\begin{array}{l}\text { - High Flexibility } \\
\text { - } \quad \text { Easy to move and share } \\
\text { - } \quad \text { Load is managed by the user on a day to day basis } \\
\text { - } \quad \text { Black outs affect only one user }\end{array}$ & $\begin{array}{l}\text { - Maintenance and repair service complex to organise in rural areas } \\
\text { - Monitoring individual plants can be expensive and difficult }\end{array}$ \\
\hline Microgrid systems & $\begin{array}{l}\text { - Improved quality (surge power, load shedding, etc.) } \\
\text { - Lower investment for compact villages } \\
\text { - Efficient Maintenance } \\
\text { - Lower Levelised cost of energy } \\
\text { - Contribute to awareness raising and involvement of local } \\
\text { communities through development of a common project }\end{array}$ & $\begin{array}{l}\text { - Higher technological and organisational complexity } \\
\text { - If there is plant failure the whole village is cut off } \\
\text { - Social rules required to distribute energy availability } \\
\text { - Local management required } \\
\text { - } \quad \text { risk of all customers being cuts off in the event of plant failure } \\
\text { - more complicated regulatory, organisational and technological organisation }\end{array}$ \\
\hline
\end{tabular}




\section{Solar Microgrids in Malawi}

In rural Malawi, solar photovoltaic technology (PV) has been used over the last 10 years and is recognised as a viable solution for improved electricity access [23]. PV systems are particularly suited to a rural Malawian context, due to compounding economic and geographical factors: limited rural coverage from the Malawian centralized grid; a mainly rural population; and low capital expenditure for PV system investment (when directly compared to other renewable energy solutions)

Malawi's off grid PV installed capacity (including Pico Solar Systems (PSP), SHS and mini-grid) has increased from 0.2 MW in 2007 to 10.4 MW in 2016 [24]. In 2012 there was an estimated 7000 PV systems present in the country, though many are known by practitioners not to be fully functional [25]. A recent market assessment for off grid technologies in Malawi found that PV systems have a significant role to play in the electrification of off-grid communities in Malawi, that PV is scalable across the entire country and its modularity and simplicity are ideally matched to the needs of off-grid communities, where technical capacity and individual household demand is low [26].

Sustainability (defined in this paper as project sustainability rather than environmental) of off-grid programs in Malawi (as well as a wider developing country context) has remained an ongoing issue for practitioners; ultimately reducing the potential impact of projects. It is difficult to predict (or ensure through actions) the sustainability of an offgrid solar PV installation as actual sustainability of such systems is the result of complex interplay between technical, economic, social and environmental factors [27]. This difficulty is evident in the number of installed solar PV systems in Malawi that fall into disrepair well before their expected lifetimes.

There is a growing consensus on the role of community microgrids in Malawi to complement and support a "stressed" national grid operated by Malawi's Energy Supply Company (ESCOM). Since 2006, a number of microgrids have been implemented in Malawi by both government and non-government organisations, with mixed experiences and lessons learned [28]. The existing microgrid systems have been left to the administration of the developer institutions to manage, operate and maintain them, without relevant regulatory framework; thereby undermining monitoring and enforcement of compliance with quality, safety and environmental standards for sustainability. Ownership and organisational structures of the microgrid governance are unclear, while accountability and transparency procedures are not clearly defined, thereby presenting challenges for authority institutions such as the Malawi Energy Regulatory Authority (MERA) to manage supporting and regulatory structures [28]. Table 3 identifies all of the solar PV minigrids currently operating in Malawi, and their location is shown in Figure 1. 
Table 3. Solar PV minigrids currently in operation in Malawi [29].

\begin{tabular}{llc}
\hline Area location & District & Size (kW) \\
\hline Nyamvuu & Nsanje & 30 \\
Chimombo & Nsanje & 15 \\
Mwalija & Chikhwawa & 15 \\
Oleole & Chikhwawa & 15 \\
Sitolo & Mchinji & 80 \\
\hline
\end{tabular}

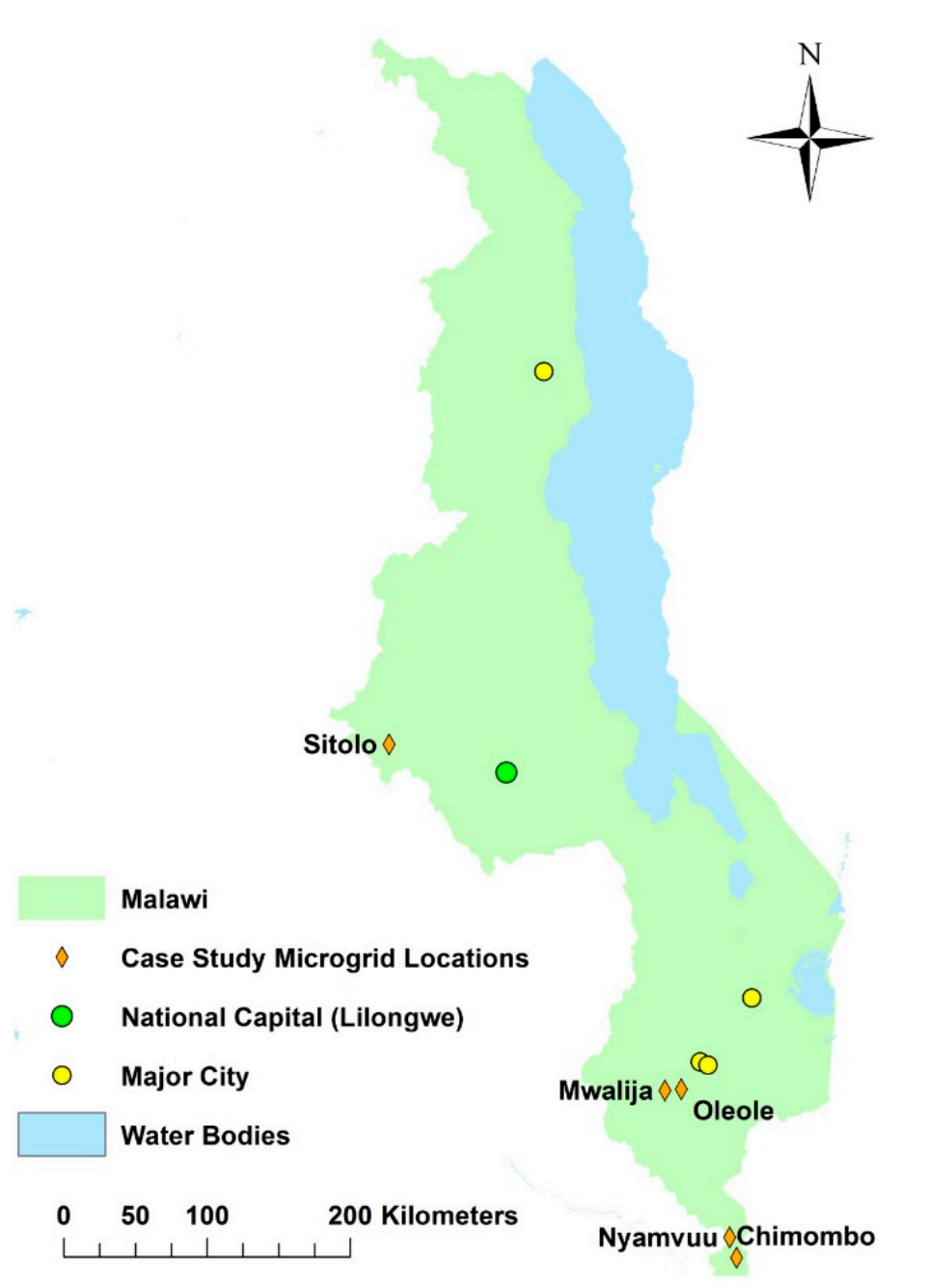

Figure 1. Location of existing solar microgrids in Malawi.

Academic and industry literature exists broadly covering solar microgrids as a rural electrification pathway [20,30,31], with some focusing on technical design and definitions [15,32,33], business models [34-36] or deployment experiences [37-40]. However, gaps exist around the use of robust and systematic planning methodologies and market assessments for microgrids specifically. Similarly, while some academic literature and project/grey literature exists on energy access in Malawi with recommendations for solar PV deployment [25,28,41], examples of feasibility or market assessments for solar microgrids in Malawi are limited, and may be a constituent part of a broader study including other forms of off-grid deployment, such as locally manufactured small wind 
turbines or PV deployment at other scales [26]. This suggests a significant gap in the understanding of the market potential of solar microgrids in Malawi exists amongst potential stakeholders, which has been identified and addressed in this paper.

\section{SOLAR MICROGRID MARKET ASSESSMENT METHODOLOGY}

This study has utilised and built upon an established methodology [26,43], which follows a three stage process to assess the market for solar microgrids in Malawi, namely: learning from existing initiatives, quantifying the potential market, and mapping the microgrid ecosystem. An outline of the three stage methodology is given in Table 4.

Table 4. Comparison of the three principal stages carried out during this market assessment.

\begin{tabular}{|c|c|c|c|c|}
\hline Stage & $\begin{array}{l}\text { Key research } \\
\text { questions }\end{array}$ & $\begin{array}{l}\text { Data collection } \\
\text { techniques }\end{array}$ & $\begin{array}{l}\text { Data processing } \\
\text { techniques }\end{array}$ & Key outputs \\
\hline $\begin{array}{l}\text { Stage 1: } \\
\text { Learning from } \\
\text { existing } \\
\text { Initiatives }\end{array}$ & $\begin{array}{l}\text { What has been } \\
\text { successful or } \\
\text { challenging in other } \\
\text { solar microgrid } \\
\text { initiatives in Africa? }\end{array}$ & $\begin{array}{l}\text { Expert interviews; } \\
\text { Local case studies site } \\
\text { visits; } \\
\text { Project report review }\end{array}$ & $\begin{array}{l}\text { Transcription/note } \\
\text { taking \& summary } \\
\text { according to specific } \\
\text { themes }\end{array}$ & $\begin{array}{l}\text { Identification of critical } \\
\text { success factors and } \\
\text { barriers to } \\
\text { implementation }\end{array}$ \\
\hline $\begin{array}{l}\text { Stage 2: } \\
\text { Quantifying the } \\
\text { potential } \\
\text { market }\end{array}$ & $\begin{array}{l}\text { How scalable are these } \\
\text { solutions? }\end{array}$ & $\begin{array}{l}\text { Primary data (from Stage } \\
\text { I case studies \& Malawian } \\
\text { RE suppliers): } \\
\text { System configuration; } \\
\text { Economic data; } \\
\text { Secondary data: } \\
\text { national statistics; } \\
\text { GIS layers }\end{array}$ & $\begin{array}{l}\text { Energy systems } \\
\text { modelling } \\
\text { (HOMERPro); } \\
\text { Geographic } \\
\text { Information Systems }\end{array}$ & $\begin{array}{l}\text { Market size and } \\
\text { distribution }\end{array}$ \\
\hline $\begin{array}{l}\text { Stage 3: } \\
\text { Mapping the } \\
\text { energy access } \\
\text { ecosystem }\end{array}$ & $\begin{array}{l}\text { What are the key risks } \\
\text { and barriers } \\
\text { preventing these } \\
\text { solutions from } \\
\text { reaching scale? } \\
\text { What can be done to } \\
\text { overcome them? }\end{array}$ & $\begin{array}{l}\text { Literature review; } \\
\text { Existing experience from } \\
\text { previous in-country } \\
\text { fieldwork and research }\end{array}$ & $\begin{array}{l}\text { Summarised according } \\
\text { to specific themes }\end{array}$ & $\begin{array}{l}\text { Recommendations for } \\
\text { targeted interventions }\end{array}$ \\
\hline
\end{tabular}

\section{Stage 1: Learning from Existing Initiatives}

Case studies of solar microgrid initiatives in Rwanda (Mesh Power) and Kenya (Steamaco and the Solar nanogrid project (SoNG)) were analysed to identify key factors for success and barriers to implementation in Malawi. The projects were intentionally chosen as they collectively offer a variety of rural electrification approaches involving variant approaches in technical solutions (e.g., AC versus DC); in developer/investor/operator (private, social, community enterprises); and in business model. 
Field visits to the partner organisations were carried out to analyse first-hand the experiences in Kenya and Rwanda of solar microgrid development in 2017. Semi-structured interviews were held with project managers, consisting of open-ended questions relating to the organisation as a whole, technical aspects and business models of their microgrids. Details of the interviews, including questions asked, are presented in Appendices Tables A2 and A3. Site visits were undertaken to view firsthand the technology and microgrid users and create a photo-file of the system. Notes were transcribed and thematically coded to draw out key themes for case study style representation. Additionally, project managers were asked to provide details of tariffs, system and business costs, used to model local systems in Malawi in Stage 2.

The purpose of this primary research was to gain insight on active real life projects, acquire a perspective on the realities of microgrid implementation, discover contributing factors to success or challenges of microgrid implementation, and draw comparisons between the influencing parameters and enabling environment in Rwanda, Kenya and Malawi. A discussion of each initiative draws out commonalities and differences between the initiatives.

\section{Stage 2: Quantifying the Market}

This stage of the methodology combines microgrid optimisation software HOMERPro with Geographic Information Systems (GIS) applications via a newly developed mapping and interpolation tool. The mapping tool uses the optimisation process offered through HOMERPro for a series of representative systems, and interpolates results to all locations within a country or region. The combined use of HOMERPro optimisation and GIS mapping builds on parts of a market assessment methodology previously used by Wind Empowerment in Ethiopia [42] and Malawi [26] specifically for small scale wind power systems. A similar geospatial study, using the OnSSET tool, has been conducted for Malawi by Korkovelos et al. [43] and other studies have been conducted in a number of other countries (including Ethiopia [44], Burkino Faso [45], Ghana [46] and Nigeria [47], making up a growing body of literature and research regarding geo-spatial technical assessments and planning support methodologies. The methodology presented here contributes to discussions by focusing in greater detail on the potential for deployment of microgrids of different sizes, explicitly considering the potential for hybrid generation (i.e., Solar-Diesel hybrids), and by quantifying the required investment (CAPEX and OPEX) per person by location. This methodology is applicable to any off-grid context, with tailored inputs, and has also been used in a recent national study in Nepal [48]. Additionally the process is not dependent on any proprietary tools: HOMERPro is used here as the industry standard for micro-grid optimisation, but any equivalent open source tool serving the same function could utilised instead. 
Figure 2 outlines the system optimisation and mapping process, along with relevant input data and key tools. Three system types were modelled; solar microgrids and diesel microgrids, to allow for cost comparison, and a solar/diesel hybrid microgrid in order to assess where hybridisation may have cost benefits.

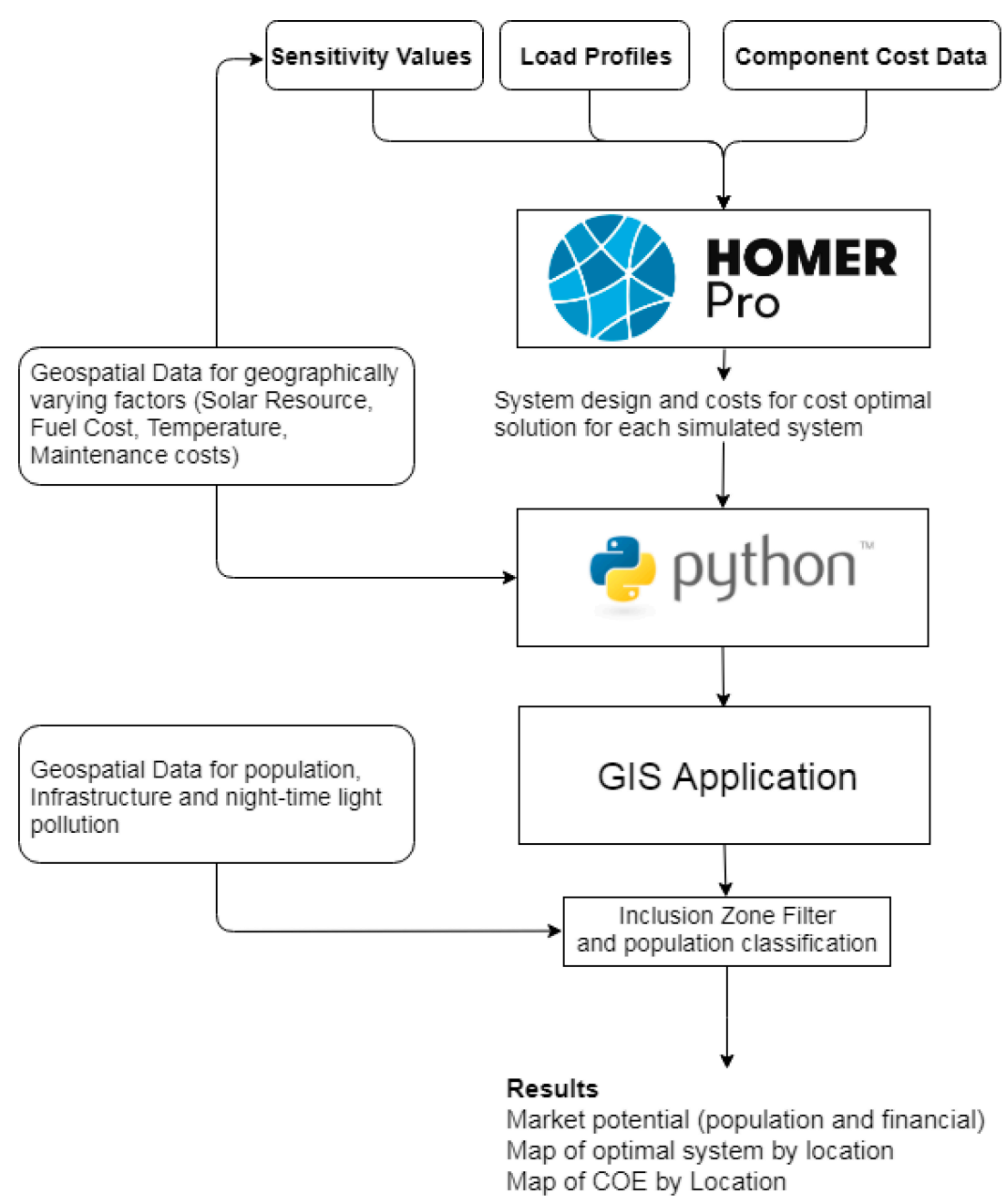

Figure 2. Process flowchart for Stage 2: Quantifying the Market.

Load profiles, component costs, and business operational, management and administrative costs used here for inputs to the techno-economic modelling process were adapted from a feasibility study for a solar microgrid in Malawi [49]. This feasibility study utilised methods for system design and business planning, building on industry standards [35,50] and employed two key elements: a qualitative site selection and customer survey exercise, utilising enumerator fieldwork to provide metrics for project feasibility; and quantitative techno-economic modelling, to inform a viable business model.

Individual customer load profiles were built from primary survey data, with the number of customers in each grid arbitrarily adjusted to provide representative microgrid designs with varying scales of generation capacity in line with case studies found in the existing initiatives. Three 
models were thus designed, to cater for high, medium and low demand levels, at $4.14 \mathrm{kWh}, 10.65 \mathrm{kWh}$ and $24.18 \mathrm{kWh}$ daily energy consumption corresponding to communities of 30,54 and 70 customers respectively. Each of these cases have a set base capital cost and fixed operations and maintenance cost to reflect the costs of the necessary infrastructure, installation and administrative costs associated with operating a microgrid of each size.

Cost curves were then built in HOMERPro for key components based on quotes collected in [49] which allow HOMERPro to optimise the system design based on resource and cost inputs. A summary of the data utilised for this study is shown in Table 5, while the costs associated with generation and storage units are given in Table 6.

Table 5. Key data for modelling and mapping for each microgrid size [49].

\begin{tabular}{llll}
\hline Microgrid parameter & Small & Medium & Large \\
\hline Number of customers & 30 & 54 & 70 \\
CAPEX (\$) & 26,850 & 52,704 & 84,560 \\
OPEX (\$/year) & 2060 & 3863 & 6215 \\
Average Daily Demand & $4.14 \mathrm{kWh}$ & $10.65 \mathrm{kWh}$ & $24.18 \mathrm{kWh}$ \\
\hline
\end{tabular}

Table 6. Cost data for generation and storage units in Malawi [49].

\begin{tabular}{llll}
\hline Component & Size & Capital (\$) & Replacement (\$) \\
\hline PV Unit & $2 \mathrm{~kW}$ & 3234 & 1600 \\
PV Unit & $4.5 \mathrm{~kW}$ & 5978 & 4970 \\
PV Unit & $10 \mathrm{~kW}$ & 13,137 & 8000 \\
Battery & $2.89 \mathrm{kWh}$ & 651 & 651 \\
Gen-set & $1 \mathrm{~kW}$ & 122.4 & 122.4 \\
\hline
\end{tabular}

The economy of scale (i.e., lower per-capacity costs for larger systems) for batteries and gen-sets is not considered in this analysis. O\&M costs were modelled as a combination of the overhead of the operator plus the anticipated maintenance trip costs, per year. Maintenance trip costs at each site were modelled as a function of the accessibility of that site, note that the OPEX per customer figures shown in Table 5 only account for the overhead associated with administrating a site of the given sizes.

In this study, four geographically varying factors were considered to define each location within Malawi: Solar Scaled Average $\left(\mathrm{kWh} / \mathrm{m}^{2} /\right.$ day), Scaled Average Temperature $\left({ }^{\circ} \mathrm{C}\right)$, Diesel Fuel Price $(\$ / \mathrm{L})$ and System O\&M trip cost (\$/year). The average solar resource data [51] and scaled average temperature [52] were used in the forms available online, whereas diesel cost data and maintenance trip costs were modelled with the use of travel time and accessibility mapping methodologies developed in [53].

The Diesel Fuel Price map was assembled through the same methodology as presented in Szabo et al. [54]. The cost at a given location was modelled as the pump price of diesel plus the fuel costs of transport 
of diesel from the nearest pump to the given location, travel times were mapped through the methodology presented in [53]. Table 7 shows the input values for the diesel price mapping process.

Table 7. Assumptions used for inputs into fuel price modelling.

\begin{tabular}{cll}
\hline Variable & Description & Assumed value \\
\hline$P_{d}$ & Pump price of diesel & $890.9 \mathrm{MK} / \mathrm{L}$ [55] \\
$c$ & Average diesel consumption rate of fuel delivery vehicle & $8 \mathrm{~L} / \mathrm{h}$ \\
$t$ & Travel time from diesel pump to site & Calculated from accessibility mapping \\
$v$ & Volume Capacity of Diesel Fuel per transport vehicle & $30 \mathrm{~L}$ \\
N/A & USD to MK exchange rate & $1 \mathrm{MK}=0.0014$ USD \\
\hline
\end{tabular}

Equation 1, with assumptions outlined in Table 8, outlines the calculation made to determine maintenance costs by location. This calculation is based on two maintenance trips per year by the system operator, assuming the rest of the maintenance activities will be carried out by the end-user community at no additional cost to the system operator.

$$
C_{\text {O\&M }}=2\left(P_{d} c t+N_{\text {Tech }} W_{\text {Tech }}\left(t+t_{\text {maint }}\right)+N_{\text {Tech }} C_{\text {lodge }} t_{\text {day }}\right)+C_{\text {overhead }}
$$

Table 8. Assumptions used for inputs into Equation 1.

\begin{tabular}{cll}
\hline Variable & Description & Assumed value \\
\hline$P_{d}$ & Pump price of diesel & $890.9 \mathrm{MK} / \mathrm{L}$ \\
$c$ & Average diesel consumption rate of vehicle & $8 \mathrm{~L} / \mathrm{h}$ \\
$t$ & Travel time from maintenance hub to site & Calculated from accessibility mapping \\
$N_{\text {Tech }}$ & Number of Technicians visiting site (inc. drive) & 2 \\
$W_{\text {Tech }}$ & Maintenance Technician Hourly Wage & $10,000 \mathrm{MK}^{1}$ \\
$t_{\text {maint }}$ & Maintenance time & $4 \mathrm{~h}$ \\
$C_{\text {lodge }}$ & Lodging Cost per Technician Per Night & $30,000 \mathrm{MK}^{1}$ \\
$t_{\text {day }}$ & Number of days spent on maintenance trip (rounded down) to indicate & Calculated from accessibility mapping \\
& number of nights of lodging required & \\
$C_{\text {Overhead }}$ & The overhead cost associated with administering the system of a given size & Dependent on system size, defined in \\
& & Table 5 \\
N/A & USD to MK exchange rate & $1 \mathrm{MK}=0.0014$ USD \\
\hline
\end{tabular}

${ }^{1}$ Taken from correspondence with solar microgrid practitioner United Purpose Malawi.

Simulations were carried out for a number of representative systems, defined by a series of sensitivity values for each of the geographically varying factors which were used as inputs for the HOMERPro microgrid design optimisation. Sensitivity values are chosen to maximise the closeness of simulated systems to the systems to be mapped, to minimise any inaccuracies introduced by interpolating between the simulated systems in the mapping process. A spatial histogram for Malawi is presented in Figure 3, with the five chosen sensitivity values for this variable are identified, by dividing the histogram into equally populated 
quantiles and setting the quantile edges as the sensitivity values. Each geographically varying factor will have a number of sensitivity values such as these.

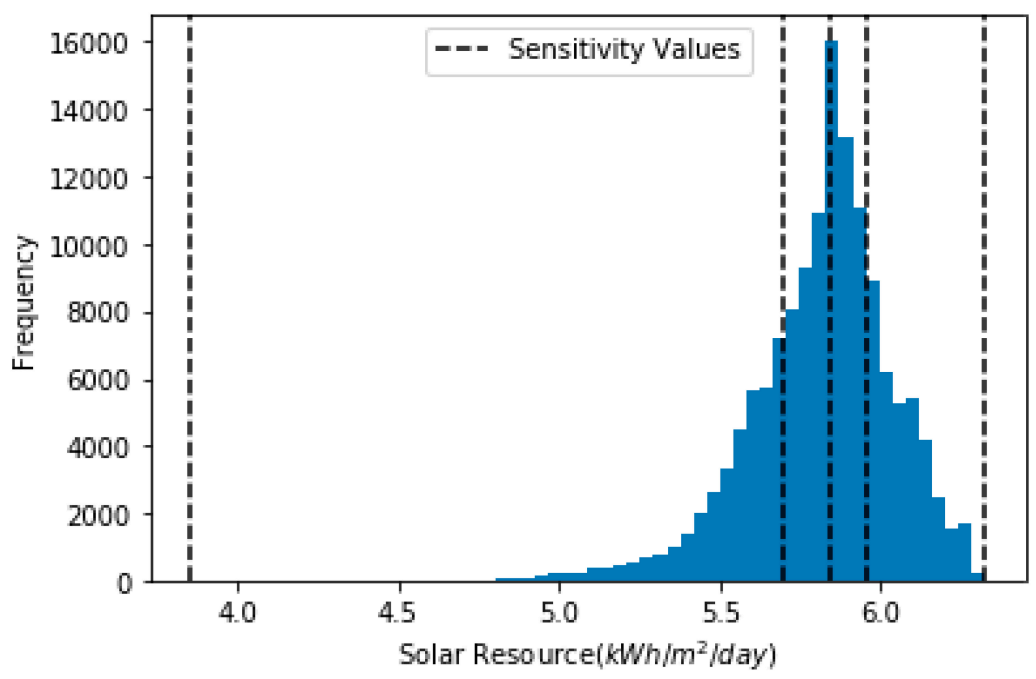

Figure 3. Spatial histogram for solar resource in Malawi.

With all the inputs identified, HOMERPro microgrid optimisation was executed and the tabulated results of the optimisation were used as inputs into the interpolation and mapping tool. This tool identifies the least cost design for each unique combination of sensitivity values. The tool then runs a linear interpolation between known outputs (i.e., the optimisation results from each combination of sensitivity values) to achieve a finer data resolution for mapping by generating intermediate results: the closer an imputed value is to a sensitivity value the more accurate it can be considered to be.

Once interpolated, the data is mapped across the country, using the values from the input maps to determine the combination of sensitivity variables to identify the optimal design (by cost of energy), and the costs associated with a given design in a given location. The interpolation process is iterated across the whole country to produce full maps of the area of interest.

In this case, three HOMERPro optimisation runs were performed for both solar microgrids and diesel microgrids, and output maps produced for each of the three cases (the low, medium and high demand grids). A household (HH) density map was then assembled in ArcGIS, taking the Population Density maps from the GPW V4 dataset [56] and dividing the raster by the average household size in Malawi (4.5 people per $\mathrm{HH}$ ) [58] to find the household density in $\mathrm{HH} / \mathrm{km}^{2}$ in the appropriate map format.

The microgrid feasibility study [49] calculated the number of paying customers needed for each size of the microgrid modelled, shown in Table 5. The HH density raster was then classified into four regions based on these customer quantity thresholds: below the HH density threshold; above the threshold for the low demand grid; above the threshold for the 
medium demand grid and above the threshold for the high demand grid. The categorised map shown in Figure 4 was then used to assign the values for the low, medium and high results to each of the appropriate regions. This resulted in a combined map with the results for each location dependent on the population density exhibited there.

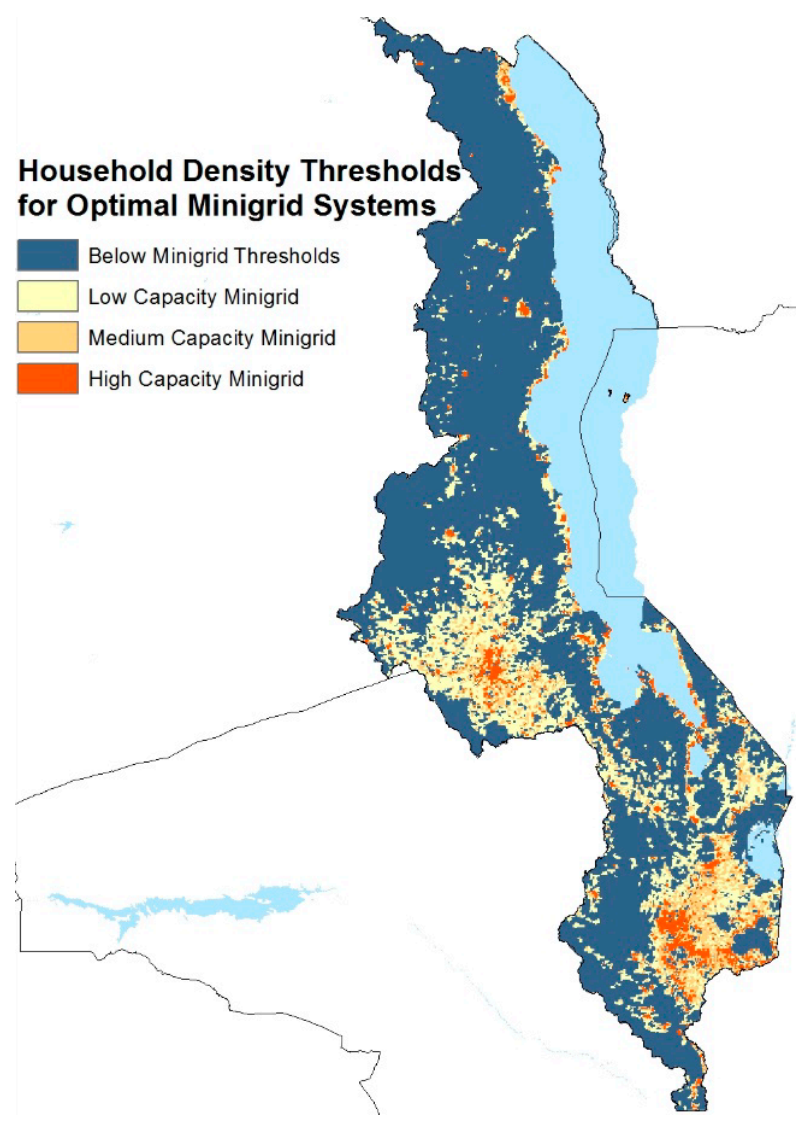

Figure 4. Optimal micro-grid size by location, based on population density data [56].

The market potential in terms of population is found by calculating the sum of the population within the regions above the minigrid population thresholds, and subtracting from this population the number of people who would be better served by grid extension or the extension of existing infrastructure. The locations where this is assumed to be the case are identified through constructing a $2 \mathrm{~km}$ buffer around existing (and planned) grid lines in Malawi [26], and combining this buffer with another $2 \mathrm{~km}$ buffer around areas exhibiting night time light pollution at levels above the average for cities in Malawi, assuming that night-time light emissions as observed by satellites correspond to artificial lighting, and therefore some degree of existing electrical infrastructure.

The buffer distance of $2 \mathrm{~km}$ was chosen by comparing the price of grid extension per $\mathrm{km}$ with the Net Present Cost of the different architectures of the high, medium and low systems. A range of thresholds were calculated in HOMERPro for the different sizes of microgrids, from $0.86 \mathrm{~km}$ to $3.21 \mathrm{~km}$, and so for this study the intermediate value of $2 \mathrm{~km}$ was used for all locations. Figure 5 shows the resulting exclusion zone 
from applying a buffer to these locations. The exclusion zone defines the area of the country not considered for microgrid implementation on the basis that these areas are best served by existing infrastructure. It is likely, however, that a number of sites within the exclusion zone may not in fact be suitable for grid extension due to population densities not being sufficient to justify installation of a substation and local LV network. Additionally, locations within the inclusion zone (currently considered as off-grid) may be preferentially connected to the grid in future where high population clusters are present, or where industrial or political policy dictates. Without higher resolution population data, and in the absence of more detailed electrification planning documents for Malawi, such considerations are beyond the scope of this assessment.

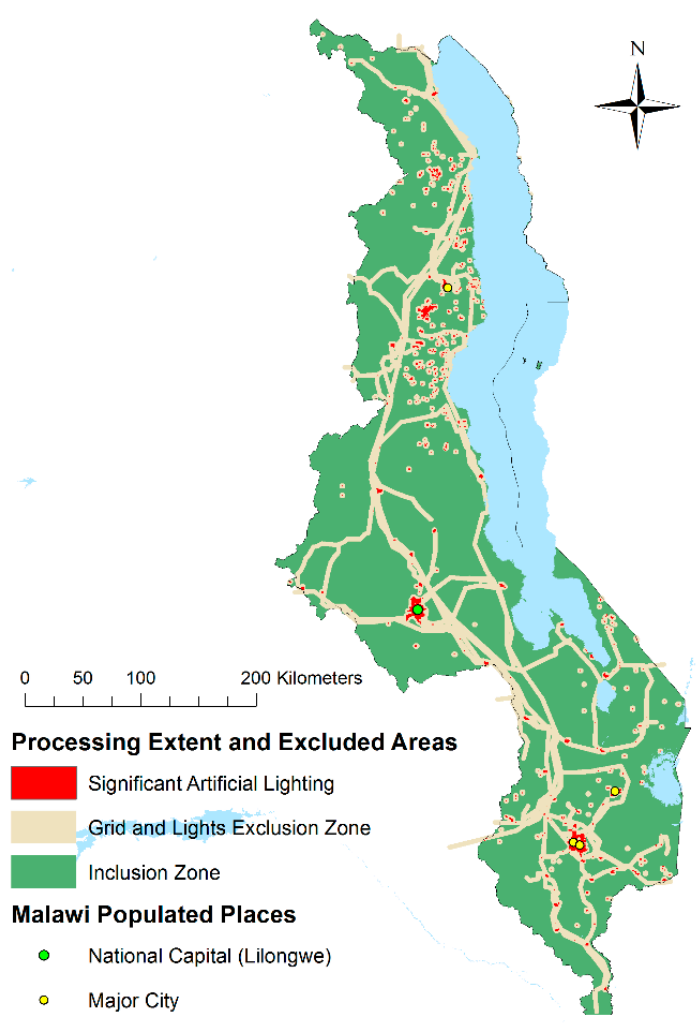

Figure 5. The inclusion and exclusion areas based on night time light pollution [59], existing and planned grid infrastructure [26] and a $2 \mathrm{~km}$ buffer around features.

The financial market potential is calculated as the total investment (CAPEX) required to cover the electrification costs for all systems in areas within the population thresholds as described, and outside of the Grid and Lights Exclusion Zone. The total yearly operational expenditure for all systems is also found, in order to determine the yearly costs accrued by all systems.

A number of assumptions were made in the process of this technoeconomic assessment and mapping process, the key limiting assumptions are detailed in Appendices Table A1. This assessment is static and considers variables only as they existed at the time of modelling, or as 
recently as data was available. Any significant changes to input data (such as maintenance costs) would have an impact on the modelled results, although whilst these changes are likely to occur within the lifetime of any newly installed system, any changes to inputs are expected to have a positive impact, reducing total system costs. It is possible, and would be prudent, to account for anticipated changes in population distribution, diesel price, solar PV prices or even increasing average temperatures due to climate change. This methodology can be used as a scenario planning tool, where input variables reflect the scenario in question. The results of this study are for the current situation and makes no explicit attempt to anticipate how the market for micro-grids will evolve, but the possibility of this is left open for future work.

\section{Stage 3: Mapping the Energy Access Ecosystem}

In the Poor People's Energy Outlook, Practical Action defined the concept of an energy access ecosystem "to describe the system conditions which could enable rapid growth in access to the range of energy services" outlined in their minimum basic standards [59]. When analysing an ecosystem related to a particular technology and region (in this case, solar microgrids in Malawi) each of the influencing parameters affecting the viability of solar microgrids for rural electrification can be identified and evaluated in order to determine effective interventions for implementation and scale up.

With this in mind, the key output of this stage of the market assessment is to identify targeted interventions to strengthen the solar microgrid ecosystem and therefore the sustainability of solar microgrid systems. This is achieved by first developing an in depth understanding of the current state of the ecosystem and identifying any barriers that are inhibiting uptake and growth of the technology. The key is then to separate fundamental "uncontrollable" barriers (e.g., lack of solar resource) from more "controllable" barriers that can be overcome by targeted interventions (e.g., lack of local capacity to install and maintain solar microgrid infrastructure).

For this study, the ecosystem has been mapped using available relevant literature and previous project case studies relating to energy access, solar $\mathrm{PV}$ and minigrid projects in Malawi over the last 10 years. Regulatory frameworks relevant to ecosystem mapping were found from relevant institutions including MERA and the Government of Malawi Department of Energy Affairs. Further input has been informed through informal consultation with private sector, government, NGOs and donors working in the Malawi energy access sector, backed up by referenced literature. 


\section{RESULTS}

\section{Learning from Existing Initiatives}

A summary of the key features differentiating the existing initiatives used to inform this market assessment is provided in Table 9. Each initiative is then described in detail.

Table 9. Comparison of key features for each initiatives considered.

\begin{tabular}{llll}
\hline Initiative parameter & MeshPower [60] & Steamaco [61] & SoNG project [62] \\
\hline Country & Rwanda & Kenya & Kenya \\
PV Array Size & $1 \mathrm{~kW}$ & $5 \mathrm{~kW}$ & $3 \mathrm{~kW}$ \\
AC/DC & $\mathrm{DC}$ & $\mathrm{AC}$ & $\mathrm{DC}$ \\
Number of Customers & 20 & 50 & \\
Energy End Use & Lights, phone charging & Variety of domestic and & Portable Battery Kits, On site \\
& & productive uses & productive use \\
Business Model & Fee for Service & Pre pay per kWh & Various \\
Payment method & Mobile Money & Mobile Money & Mobile Money \\
Ownership & Offices in UK and Rwanda & Offices in UK and Kenya & Academic Pilot, Village Energy \\
& & & Committee \\
\hline
\end{tabular}

\section{Steamaco}

Steamaco was founded in 2012 as the fall of global prices accelerated the spread of solar PV in Kenya and decentralised mini-grids gained traction globally as a rural electrification strategy. An identified market gap was noted in methods to collect and enforce payments for power: smart meters were identified as a viable solution and this gap in the market became the organisational focus. Ten pilot microgrids utilising the Steamaco-developed Bitharvester remote payment platform were installed across Kenya with impact investment funding, one of which was visited for this research. Steamaco are now operating globally, with their main income from the supply of their Bitharvester product to minigrid operators [61].

Primary microgrid customers are businesses such as salons, welders, grocery shops, and video halls, while secondary customers are domestic, with the grid providing lights, phone charging and other small appliances. The domestic customer segment currently provides lower revenues, necessitating a goal for promotion and enabling of increased energy use through higher-powered domestic appliances such as fridges, TVs and radios. However, while increased demand leading to increased revenues is desirable for microgrid operators, achieving this can be challenging in communities with subsistence-based economies. Therefore, implementing an appropriate business model is essential for customer uptake and sustained demand growth.

For pilot grids in Kenya, Steamaco is the operator and a site agent gets paid a monthly fee to conduct preventative maintenance and act as an 
interface between the customers and operator. Steamaco ensures system functionality by fielding customer calls through a service line and conducting hands-on research such as customer surveys to investigate demand, conduct high level maintenance, customer service, and identification of best practice. Pay As You go (PAYG) Payments are made via the mobile money platform M-PESA as a per kWh prepayment with payment transactions sent via SMS to the Steamaco cloud. Some systems allow customers to pay an onsite agent with cash however the M-PESA system has the highest impact on effectively streamlining the business model.

A typical system has $6 \mathrm{~kW}$ installed PV capacity and serves around 60 customers, however it is likely future microgrids will be bigger in size. The grid is supplied at AC $240 \mathrm{~V}$ through a $4 \mathrm{~kW}$ inverter with an additional $4 \mathrm{~kW}$ inverter for back up or delivering peak demand. Every customer has a breaker and fuses, sized appropriately for the demand (2A for domestic customers and $10 \mathrm{~A}$ for welding machines and power tools). The project lifetime is expected to be 20 years based on the lifetime for the equipment.

Systems generally have centralized generation with a radial hub and spoke network, with each house connected directly to the system via the hub-housed Bitharvester. For larger grids with 100 or more connections, a pole network with distribution circuits and lateral lines to each house is used, with individual meters used on $30 \mathrm{~m}$ service lines connecting to the main pole line. This is based on current Kenyan legislation for central grid connection, which futureproofs the systems to integrate with potential future grid connection.

The Bitharvester's key service is the enabling of remote payments: once payments are received a relay is opened to initiate the electrical connection. When the customer balance runs low a reminder text message is sent automatically to suggest a top-up. If the balance expires without additional funds being deposited the relay disconnects the service until payment is received. Creating flexibility of payments such as a kWh tariff, time dependent tariffs, or flat rate tariffs, increases system affordability for customers. PAYG Mobile money payments enable business customers to avoiding overpayment and reduces the entry barrier for energy use, thus enabling more responsive and robust businesses.

\section{MeshPower}

MeshPower formed in 2012 from a student society at Imperial College, UK, initially testing solar PV kiosks and portable battery kits rental in Rwanda. Realising the potential market the team decided to venture into the rural electrification sector, specifically in minigrids. The MeshPower Microgrid product was developed to provide DC power to rural communities in Rwanda with support funds from a partner investor. Following substantial growth, MeshPower at the time of fieldwork had 3 managers and 24 in-country staff operating 78 grids across Rwanda, each with between 12 to 50 customers per grid, a total of 1859 customers. 
MeshPower offer a "fee for service" model, whereby customers are billed per hour of service they receive (rather than per kW), with services including phone charging, LED lights and DC TVs. Each customer has a MeshPower account, and a database stores information on customers, their payments and allocated services. Customers top up their accounts over mobile money operator MTN Mobile Money or TIGO cash, and provided a technical fault hasn't occurred and the customer has been able to receive a service for the day, money is deducted from their account each day. If remaining funds are worth less than 1 day of service, the system will not provide further electricity for the customer until the account is topped up. Customers are not entered into a contract and are free to leave at any point, and receive a daily quota in service hours. Billing is intentionally very flexible with customers being able to pay for various tariffs based on energy or usage time if a unique deal is required.

Local site agents working in sectors look after microgrid sites, visiting twice monthly to clean solar panels as well as cleaning, inspecting and topping up lead acid batteries. Local agents also recruit new customers, install new LEDs, and discuss tariff options with customers. An issue tracking software is utilised to assign local agents to customers on specific sites. A sophisticated customer call centre is implemented to log job enquires and assign them to local agents, and an online platform is used to log enquiries. The fee for service business model means that customers can plan ahead, knowing that as long as they have paid for a certain number of days the lights will stay on. A drawback is that the model is quite restrictive, and does not allow for increased consumption without MeshPower supplying additional DC devices. A limiting factor of business growth is the poverty of the communities they work with and the associated ability to pay for energy services.

A $1 \mathrm{~kW}$ PV array is connected to sealed lead acid batteries via an industry standard charge controller at $24 \mathrm{~V}$ housed on top of a base station control box. Within the base station a boost board steps up the voltage from $24 \mathrm{~V}$ to $48 \mathrm{~V}$ for distribution. The distribution boards provide power for 10 customers per board, totaling a maximum of 50 customers for the system. The solar PV modules and base station are housed in a customer's house.

Customers are connected within a $200 \mathrm{~m}$ radius around the base station via radial connections to the central hub. Within the consumer's house a Customer Premises Equipment (CPE) acts as a hub for appliances and meter and is mounted on the wall of the house or shop. The CPE unit side meters each individual light output, and a USB output DC-DC connection to connect phone charging and DC TVs. Software running on the base station bills the customer locally, and communicates with MeshPower's central service via GSM.

The system has smart control over every service in the system, which allows for remote switching of customer devices, and limiting the maximum output of a device. Similarly, data is monitored on each system 
element and used for troubleshooting and billing. The system logs voltage and current every minute for the PV array, each battery, for all the boards, consumer unit, and power entry board. Preventative maintenance can be conducted through the remote monitoring meaning that instead of travelling, problems can be diagnosed and solved in the office, saving on time and costs.

\section{Solar NanoGrid (SoNG) project}

The SoNG project coordinated by Loughborough University [62] has been designed as an inter-disciplinary project bringing together social scientists and engineers to work together to pilot a novel technique for rural electrification in Kenya and Bangladesh. Four specific communities were identified in the target countries for microgrid projects to be installed, which was followed by extensive consultation within the chosen communities, design of the system and agreement over the business model to be employed. The installation and operation of the microgrids themselves was followed by a two year process of observation and evaluation. The case study evaluated for this paper was in Nakuru County, Kenya.

The SoNG methodology differs from other electricity providers as it starts with development as the aim and electricity as the means, whereas traditional utility models begin with electricity provision assuming development will follow. The process begun with an in depth community consultation identifying the key priorities and conducting service value tests [63] to quantify the specific desired services and productive uses in the community. This was followed by a system design and costing exercise, testing the community willingness to pay and checking for any technical constraints.

A service value test found that maize milling was required by the community but faced challenges in implementation. Similarly household lighting and TVs were also deemed important to the system users. A Village Energy Committee (VEC) was set up to own and manage the project, while local technicians were employed to run the hub. The system offers productive uses in the form of egg incubation and maize milling, but the main service is portable battery kits (PBK), which customers can collect from the hub and use in domestic dwellings. Customers pay for energy services through MPESA payments, which are uploaded onto a central server that communicates to the hub and sends information to a key fob where customers can present to the cupboard holding their battery, the key fob then turns on the electricity.

The VEC receives MPESA and cash payments from customers with a service fee taken by the in-country partner. Income is also generated through the sale of products at the energy hub such as solar lanterns and USB torches. MPESA is preferred due to less problems with corruption and being easier to track. At the time of fieldwork a plan existed to expand other business elements to include a solar kiosk offering multiple services 
including AC power tools, repair of electronic goods, and selling household wiring kits including DC lightbulbs, lightbulb holders, and junction boxes.

A $3 \mathrm{~kW}$ solar array feeds a hub battery bank at $24 \mathrm{~V}$, with charge controllers and lightning protection units included. PBK are composed of a $60 \mathrm{Wh}$ lithium ion batteries with battery monitoring, charged at $24 \mathrm{~V}$. A $150 \mathrm{~W}$ inverter is included with the system to run laptops and power tools. An open source data logger records load profiles, solar irradiance, voltage and current on solar array MPPT, current, battery voltage, and temperature, logged to an online server via GSM. Technical challenges were experienced, mainly due to equipment not being field ready. The PBK were designed innovatively to utilise second hand lithium Ion strings with expired cells, controlling cells voltage with intelligent power electronics to give a working battery pack. However with first generation pilots it was not possible to achieve sustainable cell level control. Similarly electrical logging components drained batteries making them unusable in a short time. The maize mill chosen was under powered and could not compete with diesel mills in the vicinity.

\section{Quantifying the Market Results}

Figures 6 and 7 show the Cost of Energy in $\$ / \mathrm{kWh}$ for the optimal system at each location for solar PV and diesel microgrids respectively. From these maps it can be seen that more accessible locations (closer to cities and towns) exhibit lower COE, which is due to the need for larger systems in these locations along with the lower cost of maintenance visits and in the case of the diesel microgrids the lower cost of Diesel Fuel. In every location within the inclusion zone the COE for a solar microgrid was less than a diesel mini-grid in the same location, with improvement of solar microgrid COE over diesel microgrid COE ranging from $0.03 \$ / \mathrm{kWh}$ to $1.19 \$ / \mathrm{kWh}$. Diesel microgrids are most competitive (i.e., the savings are the least) in locations where the demand/population is relatively low, but the fuel cost is also low due to proximity to nearby diesel pumps. Conversely, solar microgrids present the greatest value proposition where demand is high, or in locations far from fuel pumps. Additionally, it can be seen for both forms of generation that the areas with the greatest COE are also the furthest from traditional/formal financing institutions such as banks, potentially offering further incentive to establishing an alternative means of payment such as a mobile money system for tariff payments in these areas. 


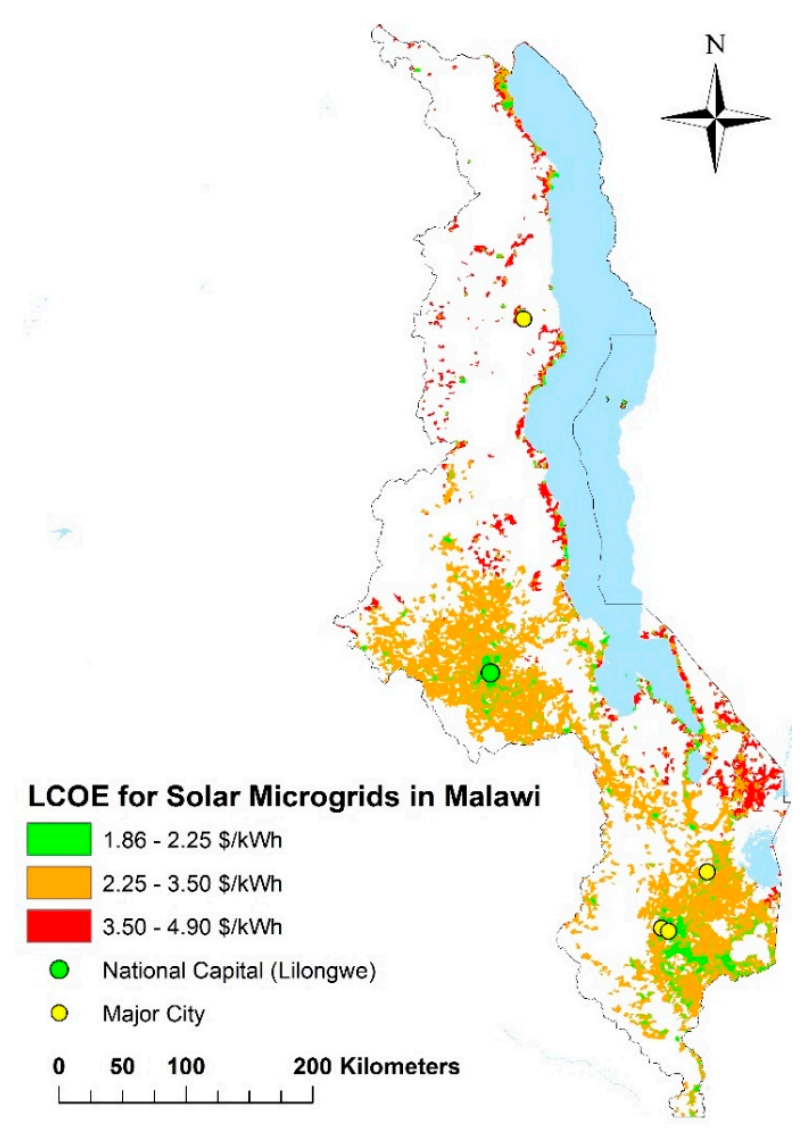

Figure 6. Cost of energy for optimally designed solar microgrid in Malawi.

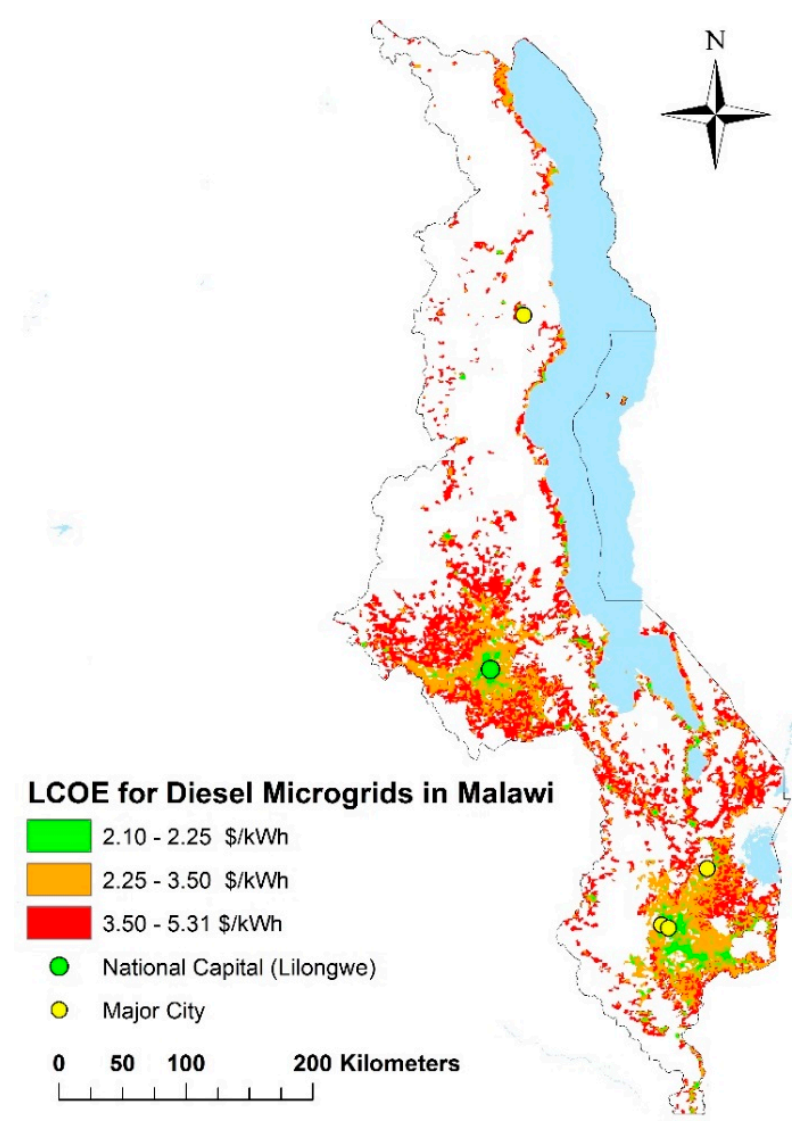

Figure 7. Cost of energy for optimally designed diesel microgrid in Malawi. 
The previous microgrid feasibility study [49] recommended an economy-of-scale tariff structure, based on field surveys, to incentivise increased energy use; the structure means that consumers using the least energy pay the highest band at $\$ 2.05$ which is still well below the estimated COE for the low-demand microgrids. The higher capacity microgrids however offer a COE broadly in agreement with the aforementioned tariff scheme.

Figure 8 shows the split of the population of Malawi by most appropriate technology, based on the population density thresholds used to assign technologies. It is noted that the population density data this figure is based on dates from 2015, and this is a purely static figure based on this data and does not account for population growth/migration or additional transmission lines. That said, the proportion of the population shown here as being most suited to grid connection may be an overestimation, as it considers all individuals within a $2 \mathrm{~km}$ buffer around existing and planned grids (and areas of bright night-time lights) as being best served by grid connection or expansion of existing infrastructure. It does not consider that that many remain unserved in these regions as an "under the grid" population due to high connection costs, informal settlement status or other political concerns. Whilst the quantification of this population is beyond the scope of this study, those living 'under the grid' may provide a potential market for high-capacity micro-grids despite the proximity to existing infrastructure.

\section{Market Potential Between Technologies by Population Density}

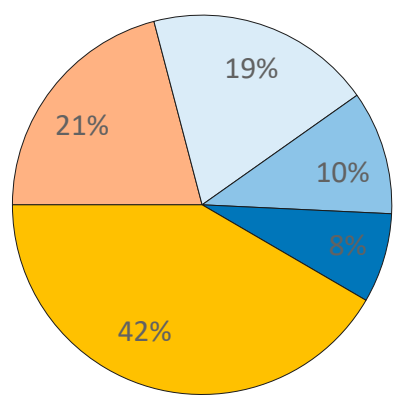

$\square$ SHS

$\square$ Medium Minigrid

$\square$ Grid Connection and existing infrastructure $\square$ Low Minigrid

- High Minigrid

Figure 8. Percentage split of Malawian population based on population distribution and the thresholds shown in Figure 4.

Based on these population density thresholds, the market potential for micro-grids in Malawi is 37\% of the total population, or approximately 6.5 million people. The CAPEX and OPEX cost variations are dominated by the microgrid size, and so in Figures 9 and 10, the highest costs can be seen to 
be within high population areas suited to high-capacity grids. Conversely, these areas are also the areas exhibiting the lowest COE, benefiting from both the lower fuel prices for diesel grids, the diversity of demand from the larger base of customers for an individual grid and lower maintenance costs due to accessibility and proximity to maintenance hubs.

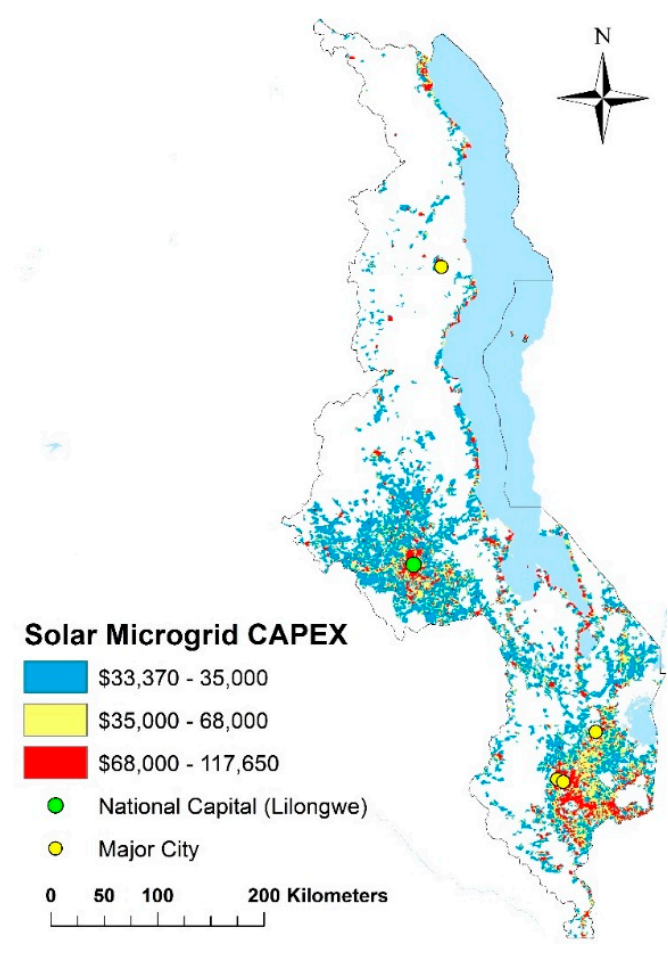

Figure 9. Capital investment required for the optimal micro-grid capacity/design at each location.

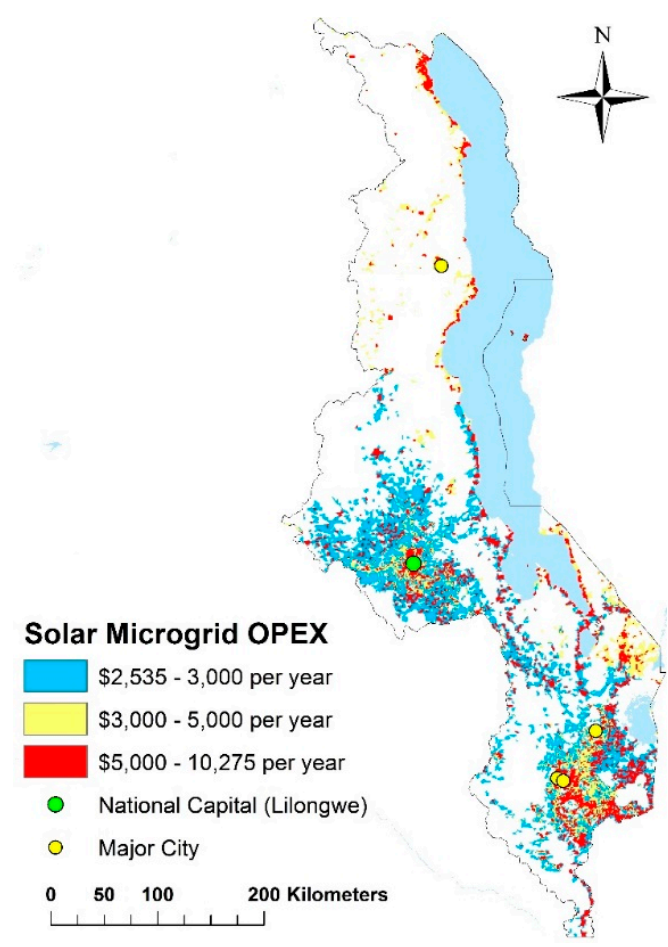

Figure 10. Annual operational costs (including fuel costs) required for the optimal micro-grid capacity/design at each location. 
Weighting the CAPEX and OPEX for the optimal solar microgrids by the number of systems required to provide electricity to everyone within the microgrid threshold regions gives values of $\$ 1.37$ bn and $\$ 109.1 \mathrm{~m}$ per year, respectively, for 6.5 million people. This equates to an average capital investment of approximately $\$ 210$ per person and an average operational expense of $\$ 17$ per person per year.

As an additional investigation, the hybridisation of solar and diesel generation was considered in order to understand the contexts in which dispatchable diesel generation may feasibly contribute to reducing the overall system cost of energy (due to lower battery storage requirements). Figure 11 shows the optimal system type from this hybrid model, constructed through the same method and inputs as previous figures. Perhaps intuitively it can be seen that the largest, more urban, populations benefit most from the inclusion of diesel generation, due to a combination of lower fuel prices and higher level of electrical demand.

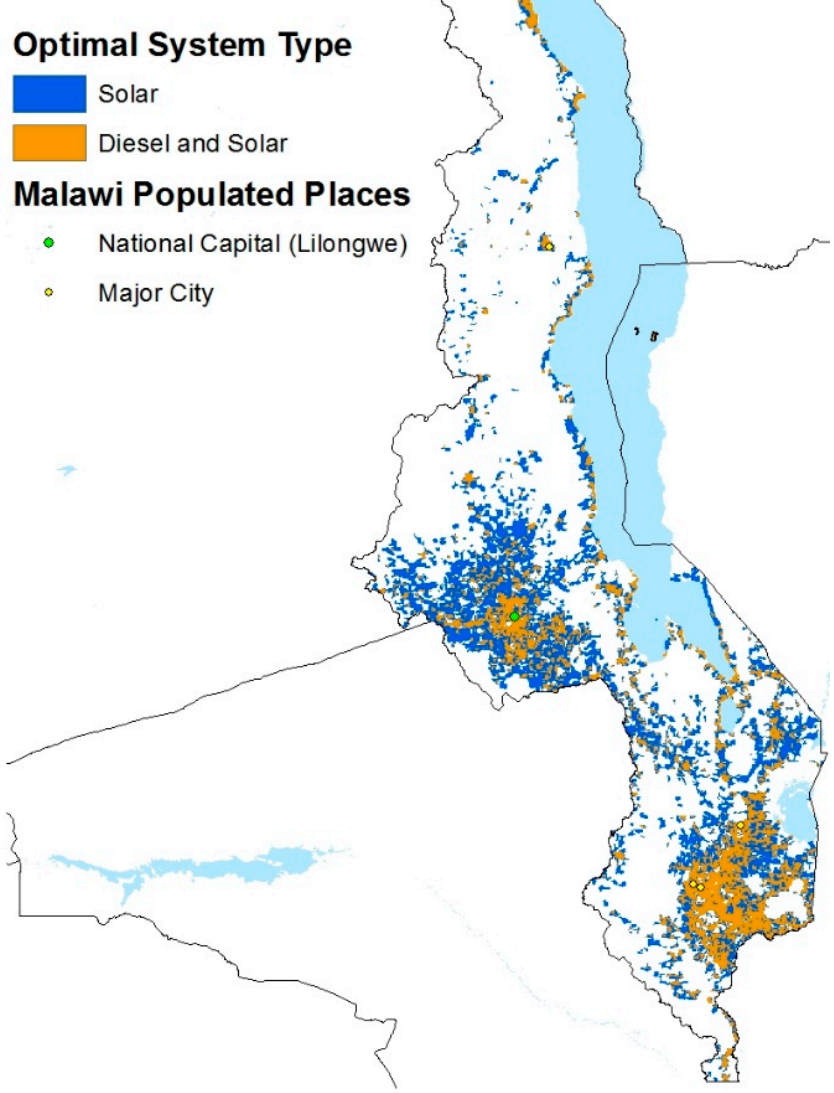

Figure 11. Optimal system type for hybrid solar-diesel microgrid system.

\section{Mapping the Malawian Solar Microgrid Ecosystem}

Systems analysis of the microgrid sector reveals the necessary elements for a functional market, and identifies challenges, opportunities and activities that can lead to sustainable implementation of the technology. The purpose of conducting an ecosystem mapping exercise is to identify 
barriers preventing the widespread deployment of solar microgrids in Malawi and provide recommendations for barrier removal to foster growth of the nascent sector. The following section provides an overview of the solar microgrid ecosystem in Malawi, presented in relevant themes. Regulatory guidance refers to mini-grids, of which microgrids are a subset. Nomenclature has been changed to microgrid for clarity.

A number of institutions contribute to the energy policy and regulatory framework in Malawi: the Ministry of Energy, including the Malawi Rural Electrification Programme (MAREP); the energy Regulatory Authority (MERA), the Electricity Supply Company (ESCOM), as well as a number of other Ministries, including Finance, Planning and Local Government. MERA evidences support for microgrids through the following statement: "MERA is committed to development of not only microgrids but the whole spectrum of renewable energy technologies, especially in the rural areas in order to complement Government's policy on increasing access to modern and clean energy at national level" [64].

The National Energy Policy (NEP) (2018) recognises the limited impact of grid extension through the Rural Electrification Fund (REF) and accordingly provides for diversified use of REF to "significantly promote development of renewable energy microgrids in support of priority areas for rural electrification" [6]. The NEP provides other provisions relating to microgrids, including support for small-scale renewable energy initiatives by communities or entrepreneurs; capacity building in areas of Renewable Energy Technologies programming, supply and services, as well as in entrepreneurship and management, taking into account gender and social issues; promoting private sector driven renewable energy technology industry; and financing off-grid solutions, from the REF.

Microgrids are promoted in the NEP as one way of accelerating electrification in locations where grid extension cannot be an economically viable electrification approach [6]. Based on the Malawi Renewable Energy Strategy (2017) [65], Malawi would have at least 50 operational microgrids by 2025. The mixed experiences of previous microgrids due to limited long-term support mechanisms has resulted in the development of legislation provisioning for microgrid support. MERA is mandated to regulate the energy sector and license energy undertakings in Malawi, and accordingly released the Malawi Minigrids framework in 2018 [66]. The framework aims to provide guidelines for the development and operation of microgrids in Malawi including: Solicitation process for microgrid development; Requirements for approval of microgrids project; Terms and conditions for registering or licensing; and Governance structures to ensure transparency and accountability in the operation of the microgrids. The framework also provides guidance on quality of supply and services standards for development and operation of the microgrids; Tariff methodologies and structures for microgrids to ensure sustainability of operations; and sustainability of microgrid operations if and when the national grid extends to the mini-grid supply areas. 
Prior to the release of the new regulatory frameworks, Malawi suffered from a complicated regulatory environment unsuited to minigrid development. Figures from Regulatory Indicators for Sustainable Energy (RISE) 2017 [67] show that on average it took between 1 and 2 years to obtain common permits to set up a minigrid facility in Malawi, and on average 120 days to obtain environmental clearance. Additionally, the cost of obtaining permits to set up a microgrid facility is the highest of all countries surveyed in the RISE report, with a quoted figure of $\$ 15,082$. The new frameworks provide welcome removal of uncertainty and bureaucratic hurdles, however their implementation is yet to transition to fully operational and further uncertainty is expected.

Capital for investment is a key challenge in Malawi as energy business models are not commonly understood by Malawian banks, and financial institutions tend to be risk averse with energy projects [68]. Interest rates in Malawi are extremely high, with banks regularly charging in excess of $40 \%$ [69]. Additional to these challenges, exchange rate fluctuations have impacted on renewable energy projects finances, especially when components are purchased from abroad. Some micro finance initiatives exist, evidenced by the existence of the Malawi Microfinance Network [70], but such organisations rarely allow enough capital to purchase a minigrid up front. Private sector investment for microgrids is limited in Malawi, with most energy related finance focused on the PSP and SHS, which has private equity and debt from local development banks providing working capital for enterprises.

Malawi's weak economy constrains energy project financing, and as a result the majority of energy projects in Malawi have been funded by overseas donor grants [25]. Donor funding for energy projects receives criticism: some state that amounts are insufficient to achieve the government and SE4All targets for energy access in Malawi, while others complain of donor funding distorting markets and hindering private sector initiatives [26]. Despite increased awareness high potential social and economic impact of energy projects, they are still considered a relatively niche sector for donors in Malawi.

Government financial support for minigrid initiatives is limited, as the majority of its funding is dedicated to expanding rural electrification through the Malawi Rural Electrification Programme MAREP which primarily supports national grid extension; enabling the electrification of trading centres at a cost of c. $90 \mathrm{~m}$ MWK per trading centre [71]. MAREP has a facility for microgrid subsidy to reduce electricity tariff to customers but it has yet to be implemented on an operational project.

Despite emerging private sector pilot projects there are no proven sustainable business plans showing payback and return on investment for microgrid systems in Malawi. A key challenge to implementing robust business models is the generally low ability and willingness to pay of a customer base comprised largely of low income subsistence farmers. In the short term absence of subsidies, microgrid developers will face 
challenges to set tariffs that balance customer's low ability to pay with sufficient income for financial sustainability.

Another challenge is that of finding adequate and suitable Productive Uses of Energy (PUE) in rural areas of Malawi [72]. As has been seen in Phase 1 of this assessment, serving PUE reduces risk in the business model as any business relying on electricity to earn money are more likely to pay than domestic customers who are inherently risky customers to a minigrid operator. In Malawi there is generally a lack of rural businesses, unlike many areas of East Africa, where solar microgrid power commonly replaces existing diesel generators [38]. Maize Milling is common in rural areas of Malawi, however solar PV powered maize mills are still at pilot stage in Malawi.

In 2018 Scottish Government funding was awarded to Community Energy Malawi (CEM) build the capacity of a local management structure to run an innovative and sustainable solar powered minigrid with a commercial model to ensure the long term sustainability of a microgrid in Sitolo for supplying electricity to homes, schools and local businesses. The project will also build local enterprise capacity, skills and knowledge to enable the use of this electricity to stimulate local economic development and build community resilience, particularly among disadvantaged women, young people and among farmers (both men and women) [73].

Evidence suggests that most of the solar PV installations in Malawi are not working due to poor installation, lack of proper maintenance or inability to acquire new batteries [74]. Reasons for this include Malawi's general lack of appropriate technical skills to install, repair or maintain the systems and communities' low financial capacity to buy replacement batteries once the initial batteries' life span runs out [28]. Given the nascent status of microgrids in Malawi, human resources for microgrid development and implementation are similarly lacking at all levels. It has also been noted that capacity within the Malawian institutional setup to drive the sector seems inadequate [26]. Furthermore, the link between national planning and district implementation is constrained by lack of both human and financial resources [71].

Challenges exist in developing the wide ranging skill sets required to successfully develop microgrid businesses, including among others: negotiation, finance, contracting, regulations, technology, partnerships, planning, data and IT. Experience is similarly lacking in devising business models that can provide viable returns through provision of electricity to rural communities by balancing the high cost of operation, maintenance and administration with the returns from poor consumers with seasonal incomes that can afford only minimal amounts of electricity. Similarly entrepreneurs suffer from a lack of knowledge about modern technology options, particularly recent innovations using hybrid systems, demand management and payment solutions.

This is being addressed in part through technical courses and Bachelor Degree courses being offered at Mzuzu University [75] which include 
techno-economic modelling of minigrids. Malawian technicians could benefit from attending international courses offered such as the microgrid academy, part of the Institute of Energy Studies \& Research-Kenya Power in Nairobi, which offers technical and entrepreneurial training programs on decentralized renewable energy solutions [76]. The district energy officer programme, led by CEM is providing some progress on energy related capacity building at a district level and could provide an opportunity for accelerating minigrid development through reducing capacity gap barriers [71].

Sustainable microgrid businesses benefit from use of mobile payment solutions to collect tariff fee payments rather than cash in-hand, ensuring transparency in reporting and accounting. The success of the existing initiatives evaluated was supported by high mobile network penetration and the availability of mobile finance platforms. In Malawi, mobile money operators including Airtel and Telecom have not yet reached a critical mass to allow cheap enough transaction fees for customers. Further challenges to uptake of mobile payment services in Malawi include mobile signal strength, coverage and reliability; high cost of metering and payment technology and platforms; risk of non-payment from customers and customer ability to pay; lack of experience with relevant business models and lack of technical knowledge and experience within communities [15].

Airtel transaction fees are applied on any withdraws from the account to another bank account. There is no charge to send money between phones but the cost to withdraw ranges from $2.5 \%$ to more than $5 \%$, even for small transactions [77]. Additional operational costs for transporting cash out of the village to the central operator and/or banked for the cooperative/community are often non-trivial. As more customers sign up to use the service the transaction costs will reduce the service costs and make use of the service more affordable. In the short term, microgrid providers will rely on local vendors to collect cash payments from customers, which adds additional cost to the microgrid business for the wages of the vendor, and also adds risk of money going missing. As mobile money penetration increases and smart meters utilising mobile payments become viable these costs will reduce, increasing profitability.

Accessing components for microgrids (including generation, distribution, batteries, monitoring and control, payment platforms) is a challenge for project developers, and tests sustainability of systems with poor access to replacement parts. The few products found in Malawi are typically expensive compared to other countries in the region, and many manufacturers do not warrant their products if imported into Malawi. Whilst the Renewable Energy Equipment Project Waiver provided by the Malawi Revenue Authority [78] helps reduce cost, the small quantities of goods currently being imported on a project by project basis offer no economy of scale. VAT has recently been waived for solar panels, solar batteries, solar inverters, solar bulbs, solar regulators, solar chargers, 
solar accumulators, solar lamps, and energy efficient bulbs which is a benefit for project developers and finances.

Beyond electricity supply technologies, availability of quality electrical equipment and appliances is limited for consumers in homes, enterprises and public facilities. Access to high efficiency products including light bulbs, TVs, fridges, etc. is particularly important for rural consumers relying on systems with limited generating capacity. Despite standards on Solar goods imposed by the Malawi Bureau of Standards, substandard PV good regularly flood the market, reducing confidence in the technology [71].

\section{DISCUSSION}

The analysis indicates that potential exists for microgrids solutions similar to those existing in East Africa can be replicated in Malawi to achieve the policy goals of increased rural electrification, however the COE is high and barriers exist in the ecosystem for widespread deployment. This section discusses key findings and their implications for microgrid implementation in Malawi, and contains specific recommendations for policy makers and practitioners to utilise the findings of the study to create impact of reduced energy poverty in Malawi.

\section{Learning from Existing Initiatives}

The existing initiatives provide a wealth of experience and lessons through their varying approaches to offering energy services through a microgrid solution, which can be utilized for microgrid implementation in Malawi. The value of deploying remote monitoring with data acquisition on load profiles to inform system performance and learn about customer energy demand has been shown for practitioners to be able to set tariffs, and design efficient technical systems and business models. Similarly, smart metering with mobile payment systems have been shown to reduce risk of non-payment and pay as you go (PAYG) structures shown to be attractive to customers.

All project developers chose sites with existing market centres and high energy use, aiming for relatively lower poverty rates or higher income levels, to increase the utilisation factor of the grid and increase revenues. Kenya and Rwanda both have limited government regulation for small generation capacities [79], and the lack of license fees have clearly benefitted all the case study projects. MeshPower's grids are exempt from tariff regulation, which is vital to do experiments with the business model. By offering a fee for service model, it is in MeshPower's interest to install low power devices so that customers consume very few kWhs, and if regulators were to bring in a minimum cost per kWh the business model would face challenges. Conversely, Steamaco charges per unit of energy, which gives an incentive to offer low efficiency appliances for their customers which increase energy consumption. 
The SoNG project has suffered from several problems, some technical (too many innovations in one go), and some social. The role of the solar microgrid technician is increasing in importance, working autonomously to maintain and expand the hub, which indicates the importance of governance and community ownership. Having projects run by Village Energy Committees allows a greater sense of ownership which can contribute to longer term sustainability, but can take longer to set up. Accordingly, despite its problems the SoNG project may be offering a solution which benefits communities to a greater degree in the long run, as enhanced community ownership inspires capacity building and empowerment. Commercial enterprises have much more efficient technical solutions with fewer problems, however the community is treated purely as customers, the monetary consideration potentially causing conflicts.

A key element to note when considering utilising lessons from Rwanda and Kenya in Malawi is the relatively difference in economic and cultural norms. Village incomes in Rwanda may be more similar to Malawi than Kenya, but Kenya's farming practices (crops, cycles, etc.) are more similar to Malawi than Rwanda's. Malawi has a GDP per Capita of USD 389 [1] which is relatively poorer than both the economy of Kenya (USD 1710) and Rwanda (USD 773) [80]. Microgrid customers are likely to have a higher ability to pay in Kenya and Rwanda than Malawi.

\section{Quantifying the Market Discussion}

In the most remote regions of Malawi the cost of energy is anticipated to be highest, due to lower population densities (and thus smaller system sizes), and higher maintenance costs. Coupled with the higher cost of energy, these populations are also likely to have a lower ability to pay given the rural-urban disparity of wealth in Malawi [81], further compounding the problem. One policy solution to this would be to offer targeted capital investment subsidies to this rural population, either through a tiered scheme based on the degree of remoteness or by subsidising the purchase of renewable energy generation (such as SHS), or a combination.

A question remains regarding the threshold between locations where SHS are preferred and where smaller scale microgrid systems are preferred. In general, microgrid systems are most cost effective where the connected households are relatively close together (that is, where population density is higher), limiting the extent and costs of the local distribution network. Microgrids are assumed to generally be a preferable technology over SHS, where viable, given the potential for microgrids to cater for higher loads and benefit from diversity of demand (and diversity of generation in the case of hybrid systems). For these, it is assumed that where solar microgrids are viable, they are the preferred option of electrification, although in some situations this may not be the case. Higher resolution population density data or site visits and community 
level modelling, including microgrid design and network reticulation, would be required in order to account for the exact case-by-case thresholds between SHS and microgrid systems.

It is possible that the proportion of the population assumed to be best served by grid electrification is an overestimation, as a significant number of people live within the grid and lights exclusion zone who may not have access to existing infrastructure due to prohibitively high connection costs. The Malawian grid also experiences regular blackouts, so even populations living close to the grid or with existing grid connection may benefit from under the grid, or grid-parallel microgrid installations. On balance, however, it is possible that larger communities within the microgrid inclusion zones are candidates for grid connection, that remains unreflected in the grid data used in this assessment, and so a small number of relatively large population centres may be incorrectly considered as microgrid candidates rather than grid extension candidates.

The COE distribution (shown in Figure 5) indicates that the cost of energy in remote areas will be highest. Individuals living in these less accessible areas are also the least likely to benefit from grid-based electrification and are also the population least able to pay for their energy services. In order to provide financially viable services, the more remote populations will require some form of gap financing or subsidy scheme. Given that the accessibility of the location is the primary influencing factor to the Cost of Energy, a policy (similar to the Renewable Energy Subsidy policy in Nepal [82], amongst other countries) where higher system subsidies are offered in areas of greater remoteness, may be beneficial.

A key output of the research is the cost of solar microgrids. They are considerably higher than grid electricity which is heavily subsidized, but as mentioned the grid is unlikely to reach areas suitable for solar microgrids within current planning horizons. Comparing solar microgrids with utility scale solar is challenging, as outside of South Africa, there are relatively few operating solar PV power plants at the utility-scale. IRENA estimates the simple average total installed cost of these projects over the period 2010 to 2017 is to be around $2.8 \$ / W$.

The market split of technologies is subject to technical and economic dynamics; rural-urban migration in particular may increase the share of the population living with grid connections, but equally increased industrialization in rural farming communities may support higher capacity (and cheaper) microgrids. Very sparse rural populations will likely remain unviable for grid or microgrid connection for the foreseeable future, leaving approximately 3.7 million people ( $21 \%$ of the population) without access to electricity or with SHS as their most practical option, constraining their opportunities for economic development. The potential for scalable or interconnected SHS may expedite the improvement of this demographic's access to electricity in the medium to long term [83] and should be investigated. Conversely, no consideration has been made here with regards to the cost of the required generation 
capacity to increase the grid connection rate of Malawi from $12.7 \%$ [84] to the $42 \%$ identified here. Detailed grid studies are required to understand the capacity of current generation, transmission and distribution assets to meet this predicted demand, comparisons should be made between the per capita costs associated with grid reinforcement and additional generation capacity and the costs for microgrid development identified here.

A market potential for solar microgrids of $37 \%$ of the total population, or approximately 6.5 million people is significant, and should be a key message for investment in the sector by donors and policy makers, and the figure given for annual per person investment of CAPEX (\$210) and OPEX (\$17) should be compared to other electrification pathway costs for details comparison and appraisal to inform electrification strategies. The figure of $37 \%$ is estimated to be the upper bound for the market potential, the actual market penetration of microgrid systems will depend on institutional support and favourable regulatory policies, recommendations for ways in which this could be accomplished are made in the following sections.

\section{Mapping the Malawian Solar Microgrid Ecosystem Discussion}

A coordinated multi-stakeholder approach is required for solar microgrids to be successful in Malawi. Investment barriers need to be reduced by providing a better understanding of risks and social benefits to investors, gradually moving Malawi away from a donor led to social impact investment economy. The lack of viable business models for microgrids is a key challenge, one that can be addressed through learning from other successful initiative in sub Saharan Africa. A focus on sustainability can be fostered through ensuring a long-term project vision with development of sustainable business models funding being sources from local and national sources as well as external donors. Learning from existing innovative projects in Malawi can be utilised to inform the nascent microgrid sector in Malawi through roundtables and working groups.

Regulatory progress is being made with the recent mini-grids framework and national energy policy, but work is still needed in putting policy into practice, something that is being addressed through the district energy officer work of CEM [71]. Whilst policies relating to quality standards of PV equipment are in place, various agencies need to do more to ensure enforcement and promote product quality standards and raise consumer awareness.

Capacity development within the solar microgrid sector is required to make the technology, at all levels ranging from project development, site selection, project management and finance as well as local capacity building for operation and maintenance. Business and finance training for microgrid developers and a greater focus on learning from international best practice will also lower barriers to entry and foster a thriving 
Malawian microgrid sector. These efforts should be maintained and iteratively improved upon in order to fill any capacity caps still present, collaboration between the private sector, government and educational institutions will be important to effectively deliver these capacity building projects.

Technical innovations for mobile payments, smart metering and datalogging are key for improving sustainable microgrid service delivery and provide primary data for further research. Utilising such technologies will also promote transparency and accountability in microgrid business strategies. Practical barriers such as high transaction fees and up-front costs associated with the inclusion of such technology can be addressed through collective action from the Malawi energy industry to lobby for reduced transaction fees. Alternatively, if opting for mobile payments, microgrid developers could consider payments to suppliers from the mobile money account, to avoid transaction fees entirely.

As one of the world's least developed countries [85], the uncertainty surrounding the ability of end users to contribute to the financial cost of any electrification system is a barrier to scalable implementation. To mitigate this barrier, embedded PUE should be prioritised as a key customer base to enable income generation and subsequent increased ability to pay amongst end-users. Additionally, the initial choice of sites for any microgrid should prioritise sites with existing market centres, and high energy use, in order to make use of existing economic activity and benefit from the lower cost of energy associated with larger capacity systems.

Further pilot projects are needed to quantify local costs of imported components for off-grid PV systems. Import duties, along with transport costs and other costs incurred by a long supply chain need to be accurately accounted for in financial modelling. Additionally, the extent of the cost benefits associated with economies of scale need to be further investigated to avoid consideration of the Malawian microgrid sector as a static entity.

\section{CONCLUSIONS}

This study has assimilated and presented key experiences from existing micro grid practitioners in Sub-Saharan Africa which can be used to inform future interventions in Malawi. Specifically, the value of remote monitoring, with data acquisition on load profiles and smart metering with mobile payment systems has been demonstrated, as has the need for enhanced community engagement, fostering productive uses of energy, and developing innovative business models that balance income for operational costs and scale up with affordable tariffs.

It has been shown that solar microgrids are cost competitive with diesel micro-grids in all modelled locations in Malawi, although the addition of dispatchable diesel generation may provide benefits in larger, more urban systems. To implement the modelled solar microgrids would cost approximately $\$ 210$ per person on average and an average operational 
expense of $\$ 17$ per person per year. Additionally it was predicted that $42 \%$ of Malawians may be most cost effectively served by existing infrastructure, $37 \%$ would be best served by microgrids and $21 \%$ would be best served by standalone, or solar-home systems. Mapping the microgrid ecosystem in Malawi has revealed barriers to widespread implementation that include: an uncertain regulatory environment, low ability for endusers to pay, lack of access to finance, lack of local capacity for design and implementation of the technology, lack of mobile money integration, and limited local supply chain for consumer appliances as well as renewable energy equipment.

Achieving a national microgrid sector in Malawi in line with Government and SE4All targets requires scale-up, replication and improvement of existing initiatives. Private sector led delivery offers the most promising approach to achieve the scale and speed required of the SE4All target of universal access to energy by 2030, however the Government of Malawi also has a critical role to play in enabling and accelerating deployment through clear and focused policy and regulatory frameworks. Furthermore, a step change in public sector funding from the Malawi government, donor partners and impact investment companies is necessary to accelerate solar microgrid implementation nationally.

\section{Future Work}

A key addition to the market quantification element of this study is an assessment of ability and willingness to pay (AWTP). It would be possible to compare the cost of energy maps produced here with the AWTP of different demographics, for example populations within urban, periurban and rural locations. AWTP for each location could be assessed through site surveys or through the Malawi Integrated Household Survey V4 dataset [86]. Given both diesel generation cost and maintenance trip costs are modelled as being dependent on diesel fuel pump price, sensitivity analyses should be conducted to consider the likely future costs of diesel fuel, and how shocks such as fuel shortages would affect the cost of energy, and the benefit of solar-diesel hybridisation where preliminarily recommended.

The levelised cost of energy for SHS in Malawi should be found and compared with the cost of energy for rural areas (i.e., for low capacity micro-grids) to verify the assumption that microgrids are best suited for electricity provision in these locations. Stakeholder judgement may be necessary in considering the "value" trade-off between a potentially slightly higher cost of energy and the capacity for productive uses. Additionally, PAYG business models should be more specifically assessed in order to understand the barriers and draw out recommendations to facilitating PAYG and/or mobile money integration into microgrids in Malawi.

The techno-economic modelling and mapping methodology demonstrated here could also be used for scenario planning for: policy 
levers such as different levels of subsidy for microgrid components, diesel price shocks (or fuel shortages), population growth, increased accessibility (or inaccessibility), post-installation demand-growth, climate change and the impacts of grid-expansion.

A specific consideration of the identified barriers to PAYGo business models and mobile money in Malawi should be undertaken, with reference made to the ways in which these have gained mainstream use in other countries in East Africa where initial barriers may be comparable. Further engagement with Malawian educational institutions is necessary to understand the content and focus of existing courses, with specific consideration of the capacity gaps identified through collaboration with private sector, third sector and government actors. Through this technical capacity assessment, recommendations to systemically improve education practices and resources for the off-grid energy sector in Malawi may be made.

\section{APPENDICES}

Table A1. Techno-economic method assumptions, justifications and limitations.

\begin{tabular}{|c|c|}
\hline Assumption & Justifications and limitations \\
\hline $\begin{array}{l}\text { Blantyre and Lilongwe are the only } \\
\text { maintenance hubs in Malawi }\end{array}$ & $\begin{array}{l}\text { All } 17 \text { Solar Energy vendors in the online Malawi YP business directory are in either } \\
\text { Blantyre or Lilongwe [87]. }\end{array}$ \\
\hline $\begin{array}{l}\text { Any off-grid installation is served by the } \\
\text { closest maintenance provider }\end{array}$ & $\begin{array}{l}\text { In the accessibility mapping methodology, the shortest travel time to Blantyre or } \\
\text { Lilongwe is calculated, meaning that it is inherently assumed that the travel times are } \\
\text { calculated for the nearest of the two. Ideally this would be the case, but in reality an } \\
\text { operator may be based in the more distant maintenance hub in certain cases. }\end{array}$ \\
\hline $\begin{array}{l}\text { All solar PV panels are installed at the } \\
\text { optimal angle for the installation's latitude }\end{array}$ & $\begin{array}{l}\text { On a site specific basis, it is standard practice to optimise the tilt-angle of each PV unit } \\
\text { based primarily on the latitude of the site. }\end{array}$ \\
\hline $\begin{array}{l}\text { Diesel is obtainable only from Malawian } \\
\text { towns and cities }\end{array}$ & $\begin{array}{l}\text { Puma Energy has } 62 \text { fuel retail sites in Malawi [88], mostly in urban areas. This } \\
\text { assumption might not be consistently justifiable however, as fuel shortages have been } \\
\text { relatively common in Malawi in recent years. Additionally, a black market for fuel } \\
\text { exists, but considering this is beyond the scope of the study. }\end{array}$ \\
\hline $\begin{array}{l}\text { Diesel is obtainable at a price of } \\
890.9 \mathrm{MK} / \mathrm{L}\end{array}$ & $\begin{array}{l}\text { Maximum pump price of Diesel for Malawian retailers was } 890.9 \mathrm{MK} / \mathrm{L} \text { at time of } \\
\text { modelling [89]. }\end{array}$ \\
\hline $\begin{array}{l}\text { Daily variation in Solar Resource and } \\
\text { temperature is uniform across Malawi }\end{array}$ & $\begin{array}{l}\text { As a relatively small country, the daylight hours at the far north and far south of the } \\
\text { country will be only slightly different due to the difference in latitude. }\end{array}$ \\
\hline $\begin{array}{l}\text { Temperature Data from World Clim V2 } \\
\text { [53] is representative of the current } \\
\text { climate in Malawi. }\end{array}$ & $\begin{array}{l}\text { This data may be increasingly inaccurate due to the effects of climate change. The data } \\
\text { is based on historical measurements for 1970-2000. Aside from an increased } \\
\text { temperature, microclimates apparent in the data may no longer be representative of } \\
\text { reality. }\end{array}$ \\
\hline $\begin{array}{l}\text { Travel times for Diesel deliveries or } \\
\text { Maintenance are by the fastest route and } \\
\text { assume constant travel from origin to } \\
\text { destination. }\end{array}$ & $\begin{array}{l}\text { The accessibility mapping methodology, used as is, provides the shortest possible time } \\
\text { for journeys. It may be that certain journeys require alternate routes or breaks in } \\
\text { travel, adding to the travel time. }\end{array}$ \\
\hline
\end{tabular}


Table A1. Cont.

\begin{tabular}{|c|c|}
\hline Assumption & Justifications and limitations \\
\hline $\begin{array}{l}\text { Grid extension is motivated by the least } \\
\text { cost electrification of households }\end{array}$ & $\begin{array}{l}\text { Grid extension is highly politicised and often not rolled out in a manner purely } \\
\text { informed by economic trade-offs. }\end{array}$ \\
\hline $\begin{array}{l}\text { Any household within the grid and lights } \\
\text { exclusion zone is best served by grid } \\
\text { extension, or is currently served }\end{array}$ & $\begin{array}{l}\text { As a result this study makes no consideration of so called "under the grid" populations, } \\
\text { which may in reality be a significant market for off-grid provision. }\end{array}$ \\
\hline $\begin{array}{l}\text { Household density thresholds are } \\
\text { calculated on the basis that radial grids } \\
\text { cease to be viable once the distribution } \\
\text { line exceeds } 500 \mathrm{~m}\end{array}$ & $\begin{array}{l}\text { This may not be equally valid for low, medium and high capacity micro-grids. } \\
\text { Additionally, the individual site topography and population distribution will dictate } \\
\text { what lengths of radial distribution are feasible. }\end{array}$ \\
\hline $\begin{array}{l}\text { Areas best served by the grid are } \\
\text { considered as existing solely within the } \\
\text { grid and lights exclusion buffer. }\end{array}$ & $\begin{array}{l}\text { In reality grid extension considerations are complex, and should account for } \\
\text { topography, population densities, cost of installing substations, distance from existing } \\
\text { substations, existing grid constraints and grid stability. These considerations are, } \\
\text { however, beyond the scope of this study. }\end{array}$ \\
\hline $\begin{array}{l}\text { Micro-grid systems are more cost-effective } \\
\text { and suitable for electrification than stand- } \\
\text { alone systems above the given household } \\
\text { density threshold. }\end{array}$ & $\begin{array}{l}\text { There is a degree of uncertainty surrounding the tipping point between stand-alone } \\
\text { and micro-grid preference, and as this methodology does not directly address this or } \\
\text { make comparisons, it may be the case that in locations of relatively low population } \\
\text { density, standalone systems are preferable to the low capacity micro-grid. }\end{array}$ \\
\hline
\end{tabular}

Table A2. Details of interviews held.

\begin{tabular}{lll}
\hline Name of practitioner & Company & Location \\
\hline Emily Moder & Steamaco & Nairobi, Kenya \\
Lukas Lukoschek & MeshPower & Kigali, Rwanda \\
Anna Clements & Oxford University (SoNG Project) & Oxford, UK \\
Evan Kimani & SoNG Project & Nakuru, Kenya \\
\hline
\end{tabular}

Table A3. Details of questions.

\begin{tabular}{|c|c|}
\hline Theme & Questions \\
\hline Business & $\begin{array}{l}\text { - Please provide a brief overview of the business, providing information on the following: } \\
\text { - Who are your customers? } \\
\text { - Who operates your microgrid systems? } \\
\text { - How much do customers pay (Tariff structures Payment methods (PAYG)? } \\
\text { - Are there any benefits/drawbacks to running it this way? } \\
\text { - Is there anything that is different to the business structure now than when it started? }\end{array}$ \\
\hline Technical & $\begin{array}{l}\text { - Could you give a brief overview of a typical minigrid system, the main components of the system and how it works? } \\
\text { - What were the main technical barriers and how were they overcome? } \\
\text { - What safety features are present? } \\
\text { - Do you cater for demand growth when you size the systems? Probe } \\
\text { - Is diagnostic data used for preventative maintenance? } \\
\text { - What data logging do the systems do? } \\
\text { - What do you do with the data you get? }\end{array}$ \\
\hline
\end{tabular}


Table A3. Cont.

\begin{tabular}{lll}
\hline Theme & Questions \\
\hline Regulatory & - & Do you receive support from the government? \\
& - & Are there any policies that influence your project? \\
& - & How could government policies better support your microgrid programme? \\
\hline Finance & - & What level of finance was used to set up the project \\
& - Would micro-finance be appropriate/is it used? What level? \\
& - & Does your system rely on mobile money? \\
\hline Capacity & - What level of training is required for the system operators? \\
& - If you were to set up in Malawi would you need in terms of a local partner/(s)? \\
& - What other in country market actors (Such as renewable energy associations) would assist the set-up of a \\
\hline Barriers/ & project in Malawi? \\
Challenges & - What are the main challenges you have faced to nano-grid implementation?
\end{tabular}

\section{AUTHOR CONTRIBUTIONS}

$\mathrm{AE}$ conducted the fieldwork and primary data gathering, planned the research strategy and coordinated the write up. AA carried out the research for Stage 2 of the methodology combining GIS mapping with techno-economic modelling. DF, SS and SG informed the research design and collaborated on data analysis. AE and AA wrote the paper with input from all authors.

\section{CONFLICTS OF INTEREST}

The authors declare that there is no conflict of interest.

\section{FUNDING}

This research was funded by EPSRC through Global Challenges Research Funding and the Scottish Government International Development Fund.

\section{ACKNOWLEDGMENTS}

The authors acknowledge the support of Steamaco, MeshPower and the Solar NanoGrid project in supporting the fieldwork and data collection for this project.

\section{REFERENCES}

1. World Bank. Country Profile. World Development Indicators Database. Available from: http://databank.worldbank.org/data/views/reports/ reportwidget.aspx?Report Name=CountryProfile\&Id=b450fd57\&tbar=y\&dd= y\&inf=n\&zm=n\&country=MWI. Accessed 2018 Mar 28.

2. Trading Economics. Malawi Inflation Rate. 2015. Available from: https://tradingeconomics.com/malawi/consumer-price-index-cpi. Accessed 2018 Mar 28. 
3. SE4All. SE4All Africa Hub-Supporting Sustainable Energy for All in Africa. 2017. Available from: https://www.se4all-africa.org/. Accessed 2017 Aug 3.

4. United Nations. Sustainable development goals-United Nations. 2015. Available from: http://www.un.org/sustainabledevelopment/sustainabledevelopment-goals/. Accessed 2017 Aug 3.

5. World Bank. Electric power consumption (kWh per capita). Available from: https://data.worldbank.org/indicator/EG.USE.ELEC.KH.PC?view=map. Accessed 2018 Mar 28.

6. Malawi National Energy Policy. 2018. Available from: https://energy.gov.mw/ index.php/blog/downloads/policies-strategies. Accessed 2019 Sep 12.

7. Malawi Renewable Energy Strategy. Lilongwe (Malawi): Malawi Energy Regulatory Authority (MERA); 2017.

8. Support Study for DFID Low Carbon Mini Grids. Identifying the gaps and building the evidence base on low carbon mini-grids. Final Report. London (UK): DfID; 2013. Available from: https://assets.publishing.service.gov.uk/ government/uploads/system/uploads/attachment data/file/278021/IEDgreen-min-grids-support-study1.pdf. Accessed Accessed 2018 Mar 28.

9. Roche OM, Blanchard RE. Design of a solar energy centre for providing lighting and income-generating activities for off-grid rural communities in Kenya. Renew Energy. 2018;118:685-94.

10. Stojanovski O, Thurber M, Wolak F. Rural energy access through solar home systems: Use patterns and opportunities for improvement. Energy Sustain Dev. 2017;37:33-50.

11. Lemaire X. Solar home systems and solar lanterns in rural areas of the Global South: What impact? Wiley Interdiscip Rev Energy Environ. 2018;7(5):e301.

12. Azimoh CL, Klitenberg P, Wallin F, Karlsson B. Illuminated but not electrified: An assessment of the impact of Solar Home System on rural households in South Africa. Appl Energy. 2015;155:354-64.

13. Arraiz I, Calero C. From Candles to Light: The Impact of Rural Electrification. Washington, D.C. (US): IDB; 2015. IDB Work Pap Ser N. IDB-WP-599.

14. Chattopadhyay D, Bazilian M, Lilienthal P. More power, less cost: Transitioning up the solar energy ladder from home systems to mini-grids. Electr J. 2015;28(3):41-50.

15. International Electrotechnical Commission. Technical Specification Microgrids-Part 1: Guidelines for microgrid projects planning and specification. Geneva (Switzerland): IEC; 2017. Available from: https://webstore.iec.ch/preview/info iec62898-1\%7Bed1.0\%7Den.pdf. Accessed 2019 Apr 11.

16. Kempener R, Lavagne O, Saygin D, Skeer J, Vinci S, Gielen D. Off-Grid Renewable Energy Systems: Status and Methodological Issues. Abu Dhabi (United Arab Emirates): IRENA; 2015. Available from: http://www.irena.org/DocumentDownloads/Publications/IRENA Off-grid Renewable Systems WP 2015.pdf. Accessed 2018 Jun 20.

17. WEO-2017 Special Report: Energy Access Outlook. Paris (France): IEA; 2017. Available from: https://webstore.iea.org/weo-2017-special-report-energyaccess-outlook. Accessed 2018 Jan 21. 
18. Solar PV in Africa: Costs and Markets. Abu Dhabi (United Arab Emirates): IRENA; 2016. Available from: https://www.irena.org/DocumentDownloads/ Publications/IRENA Solar_PV Costs Africa 2016.pdf. Accessed 2017 Aug 4.

19. Chaurey A, Krithika PR, Palit D, Rakesh S, Sovacool BK. New partnerships and business models for facilitating energy access. Energy Policy. 2012;47(Suppl. 1):48-55.

20. MICROGRIDS Promotion of microgrids and renewable energy sources for electrification in developing countries. Available from: https://ec.europa.eu/energy/intelligent/projects/sites/iee-projects/files/ projects/documents/microgrids final report.pdf. Accessed 2018 Mar 28.

21. Multi-Tier Framework for Measuring Energy Access. Available from: https://www.esmap.org/node/55526. Accessed 2018 Mar 28.

22. BIF. BIF2 Facilitating Systemic Change in the Malawi Pico Solar Products Market. 2014. Available from: https://www.bifprogramme.org/sites/default/files/attachments/facilitating_sy stemic change in the malawi psp market.pdf. Accessed 2018 Jan 20

23. DfID. A review of solar electricity investment opportunities in Malawi. London (UK): DfID; 2015.

24. IRENA. Renewable Energy Statistics 2017. Available from: https://www.irena.org/. Accessed 2017 Aug 3.

25. Zalengera C, Blanchard RE, Eames PC, Juma AM, Chitawo ML, Gondwe KT. Overview of the Malawi energy situation and A PESTLE analysis for sustainable development of renewable energy. Renew Sustain Energy Rev. 2014;38:335-47.

26. Sumanik-Leary J, Org M, Little M, Persson J, Kalonga C, Eales A. Market Assessment for Locally Manufactured PV-Wind Hybrid Systems in Malawi. Glasgow (UK): University of Strathclyde; 2016.

27. Dauenhauer P, Frame D, Eales A, Strachan S, Buckland H. Sustainability Evaluation of Community-Based, Solar Photovoltaic Projects in Malawi. Energy Sustain Soc. Forthcoming 2019.

28. Eales A, Unyolo B. Renewable Energy Mini-grids in Malawi: Status, Barriers and Opportunities. Glasgow (UK): University of Strathclyde; 2018.

29. Zalangera C. Unpacking Energy Systems Vulnerability and Actions for Resilience: Lesson from Malawi. Presented at Low Carbon Energy for Development Network; 2019 May 1-3; University of Strathclyde, Glasgow, UK.

30. Schnitzer D, Lounsbury DS, Carvallo JP, Deshmukh R, Apt J, Kammen DM. Microgrids for Rural Electrification: A critical review of best practices based on seven case studies. Washington, D.C. (US): United Nations Foundation; 2014. Available from: http://energyaccess.org/wp-content/uploads/2015/07/ MicrogridsReportFINAL high.pdf. Accessed 2018 Mar 30.

31. Francks E. The Future of Solar Microgrids in Sub-Saharan Africa: How social enterprises can accelerate the spread of renewable energy to off-grid communities [Thesis]. Santa Clara (CA, US): Santa Clara University; 2017. Available from: http://globalsocialbenefit.institute/pdf/Francks.Thesis.pdf. Accessed 2018 Mar 28. 
32. Williams NJ, Jaramillo P, Cornell B, Lyons-galante I, Wynn E. Load Characteristics of East African Microgrids. In: Load Characteristics of East African Microgrids; 2017 Jun 27-30; Accra, Ghana. Piscataway (US): IEEE; 2017. p. 236-41.

33. Alzola JA, Vechiu I, Camblong H, Santos M, Sall M, Sow G. Microgrids project, Part 2: Design of an electrification kit with high content of renewable energy sources in Senegal. Renew Energy. 2009;34(10):2151-9.

34. Williams NJ, Jaramillo P, Taneja J, Ustun TS. Enabling private sector investment in microgrid-based rural electrification in developing countries: A review. Renew Sustain Energy Rev. 2015;52:1268-81.

35. Safdar T. Business models for mini-grids Smart Villages Business models for mini-grids. Oxford (UK): Smart Villages; 2017. Available from: http://e4sv.org/wp-content/uploads/2017/05/TR9.pdf. Accessed 2018 Mar 30.

36. Knuckles J. Business models for mini-grid electricity in base of the pyramid markets. Energy Sustain Dev. 2016;31:67-82.

37. Payen L, Bordeleau M, Young T. Developing Mini-grids in Zambia: How to build sustainable and scalable business models? London (UK): Practical Action; 2016.

38. Blodgett C, Moder E, Kickham L, Leaf H. Powering Productivity: Early Insights into Mini Grid Operations in Rural Kenya. Seattle (WA, US): Vulcan Impact Investing; 2016. Available from: http://www.vulcan.com/MediaLibraries/ Vulcan/Documents/Kenya-Mini-Grids-White-Paper-VI2.pdf. Accessed 2018 Mar 26.

39. Kirubi C, Jacobson A, Kammen DM, Mills A. Community-Based Electric MicroGrids Can Contribute to Rural Development: Evidence from Kenya. World Dev. 2009;37(7):1208-21.

40. Contejean A, Verin L. Making mini-grids work: Productive uses of electricity in Tanzania. IIED Working Paper. London (UK): IIED; 2017.

41. Gamula GET, Hui L, Peng W. An Overview of the Energy Sector in Malawi. Energy Power Eng. 2013;5:8-17.

42. Eales A, Sumanik-Leary J, Latoufis K. Market Assessment for Locally Manufactured Small Wind Turbines in Ethiopia. London (UK): Wind Empowerment; 2016. Available from: https://drive.google.com/file/d/ 0Bxu4sNbmC6BzaVRvQnZ0OTRKRWM/view. Accessed 2018 Sep 12.

43. Korkovelos A, Khavari B, Sahlberg A, Howells M, Arderne C. The Role of Open Access Data in Geospatial Electrification Planning and the Achievement of SDG7. An OnSSET-Based Case Study for Malawi. Energies. 2019;12(7):1395.

44. Dalla Longa F, Strikkers T, Kober T, van der Zwaan B. Advancing Energy Access Modelling with Geographic Information System Data. Environ Model Assess. 2018;23(6):627-37.

45. Moner-Girona M, Bódis K, Huld T, Kougias I, Szabó S. Universal access to electricity in Burkina Faso: Scaling-up renewable energy technologies. Environ Res Lett. 2016;11(8):084010.

46. Kemausuor F, Adkins E, Adu-Poku I, Brew-Hammond A, Modi V. Electrification planning using Network Planner tool: The case of Ghana. Energy Sustain Dev. 2014;19(1):92-101. 
47. Mentis D, Welsch M, Fuso Nerini F, Broad O, Howells M, Bazilian M, et al. A GIS-based approach for electrification planning-A case study on Nigeria. Energy Sustain Dev. 2015;29:142-50.

48. KAPEG-National Market Assessment for Solar and Wind Hybrid System in Nepal. Available from: https://online.kapeg.com.np/news-andevents/national-market-assessment-for-solar-and-wind-hybrid-system-innepal. Accessed 2019 Dec 4.

49. Eales A, Archer L, Buckland H, Frame D, Galloway S. Feasibility Study for a Solar PV Microgrid in Malawi. In: 2018 53rd International Universities Power Engineering Conference; 2018 Sep 4-7; Glasgow, UK. Piscataway (US): IEEE; 2018.

50. What size shall it be? Born (Germany): GIZ; 2016.

51. World Bank. Global Solar Atlas-Downloads. Available from: http://globalsolaratlas.info/downloads/malawi. Accessed 2018 Sep 12.

52. Fick SE, Hijmans RJ. WorldClim 2: new 1-km spatial resolution climate surfaces for global land areas. Int J Climatol. 2017;37(12):4302-15.

53. Weiss DJ, Nelson A, Gibson HS, Temperley W, Peedell S, Lieber A, et al. A global map of travel time to cities to assess inequalities in accessibility in 2015. Nature. 2018;553:333-6.

54. Szabó S, Bódis K, Huld T, Moner-Girona M. Energy solutions in rural Africa: mapping electrification costs of distributed solar and diesel generation versus grid extension. Environ Res Lett. 2011;6:034002.

55. Pump prices up in Malawi in response to Kwacha weakness-The Times Group Malawi. Available from: https://times.mw/pump-prices-up-in-malawiin-response-to-kwacha-weakness/. Accessed 2019 Nov 4.

56. NASA. UN WPP-Adjusted Population Density, v4.10: Gridded Population of the World (GPW), v4. Available from: https://sedac.ciesin.columbia.edu/data/set/gpw-v4-population-densityadjusted-to-2015-unwpp-country-totals-rev11. Accessed 2018 Sep 12.

57. Household Size and Composition Around the World 2017 Data Booklet. New York (US): United Nations; 2017.

58. Román MO, Wang Z, Sun Q, Kalb V, Miller SD, Molthan A, et al. NASA’s Black Marble nighttime lights product suite. Remote Sens Environ. 2018;210:113-43.

59. Practical Action. Poor Peoples Energy Outlook 2014. Available from: https://infohub.practicalaction.org/oknowledge/bitstream/11283/556929/9/PP EO English 2014 LowRes New.pdf. Accessed 2017 Aug 15.

60. MeshPower Home. Available from: http://www.meshpower.co.rw/. Accessed 2018 May 2.

61. Steamaco. Available from: http://steama.co/. Accessed 2018 Apr 3.

62. Rezwan Khan M, Brown ED. DC Nano-grids: a low cost PV based solution for livelihood enhancement in rural Bangladesh. In: Schafer M, Kammen D, Kebir N, Philipp D, editors. Innovating Energy Access for Remote Areas: Discovering Untapped Resources. Proceedings of the International Conference; $2014 \mathrm{Apr}$ 10-12, University of California, Berkeley, USA. Berlin (Germany): Universitätsverlag der TU Berlin; 2014. p. 79-83. Available from: https://repository.lboro.ac.uk/articles/DC Nano-grids a low cost PV based 
solution for livelihood enhancement in rural Bangladesh/9486125.

Accessed 2019 Nov 4.

63. Clements A, Wheeler S, Mohr A, McCulloch M. The Service Value Method for Design of Energy Access Systems in the Global South. Proc IEEE. 2019;107(9):1940-66.

64. Malawi Regulatory Authority. Tariff Framework for Mini Grids in Malawi. Available from: http://www.meramalawi.mw/index.php/resource-center/ other-regulatory-tools/send/20-other-regulatory-tools/71-tariff-frameworkfor-mini-grids-in-malawi. Accessed 2018 Mar 27.

65. Malawi Renewable Energy Strategy. Lilongwe (Malawi): Malawi Energy Regulatory Authority (MERA); 2016.

66. Legal and Regulatory Framework for Mini Grids. Available from: https://www.meramalawi.mw/index.php/resource-center/other-regulatorytools/download/20-other-regulatory-tools/70-legal-and-regulatoryframework-for-mini-grids. Accessed 2019 Nov 6.

67. Foster V, Portale E, Bedrosyan D, Besnard JSG, Parvanyan T. Policy Matters: Regulatory Indicators for Sustainable Energy. Washington, D.C. (US): The World Bank Group; 2018. p. 1-140.

68. Coley W, Unyolo B, Eales A, Frame D. Mapping Opportunities for Microfinance and Renewable Energy Services in Malawi. Glasgow (UK): Strathclyde Energy for Development; 2019.

69. Malawi Energy Access Workshop; 2018 Jul 4-5; Ufulu Gardens, Lilongwe, Malawi.

70. Malawi Microfinance Network (MAMN). Available from: https://www.mamn.mw/. Accessed 2019 Nov 7.

71. Buckland H, Eales A, Brown E, Cloke J, Blanchard R, Yona L, et al. Malawi District Energy Officer Blueprint: Recommendations Paper. Glasgow (UK): University of Strathclyde; 2017. Available from: https://pure.strath.ac.uk/portal/en/publications/malawi-district-energyofficer-blueprint(bd5a94cf-68a2-434a-b11a-cb98de6da4b4).html. Accessed 2018 Apr 4.

72. Eales A, Buckland H, Frame D, Unyolo B, Gondwe C, Kaunda M. Productive Use of Solar PV in Rural Malawi: Feasibility Studies. Glasgow (UK): University of Strathclyde; 2017. Available from: https://pureportal.strath.ac.uk/en/ publications/productive-use-of-solar-pv-in-rural-malawi-feasibility-studies. Accessed 2019 Apr 11.

73. CEM. Community Energy Malawi. 2016. Available from: https://www.communityenergymalawi.org/. Accessed 2019 Jan 18.

74. Frame D, Dauenhauer P. Sustainability of Solar PV Institutions in Malawi. Available from: https:/pure.strath.ac.uk/ws/portalfiles/portal/62670554/ Frame Dauenhauer 2015 sustainability of solar PV institutions in Malawi.pdf. Accessed 2017 Aug 28.

75. Mzuzu University. Available from: https://www.mzuni.ac.mw/. Accessed 2019 Nov 6. 
76. The Micro Grid Academy-Institute of Energy Studies \& Research (IESR). Available from: http://www.iesr.ac.ke/index.php/research/mga. Accessed 2019 Nov 6.

77. Airtel. Airtel Transaction Fees. Available from: https://airtel.mw/airtelmoney/transaction fees. Accessed 2019 Jul 21.

78. Malawi Revenue Authority-Customs and Excise tax incentives. Available from: https://www.mra.mw/tax-update/customs-and-excise-tax-incentives. Accessed 2019 Nov 6.

79. Irena. Policies and Regulations for Private Sector Renewable Energy Minigrids. Available from: http://www.irena.org/DocumentDownloads/ Publications/IRENA Policies Regulations minigrids 2016.pdf. Accessed 2017 Sep 28.

80. GDP per capita (current US\$). Available from: https://data.worldbank.org/indicator/NY.GDP.PCAP.CD. Accessed 2019 Dec 5.

81. World Bank. Poverty \& Equity Data Portal. Available from: http://povertydata.worldbank.org/poverty/country/MWI. Accessed $2018 \mathrm{Mar}$ 28.

82. Government of Nepal Ministry of Population and Environment Renewable Energy Subsidy Policy, 2073 BS. Kathmandu (Nepal): Government of Nepal; 2016.

83. Bowes J, Booth C, Strachan S. System interconnection as a path to bottom up electrification. In: 2017 52nd International Universities Power Engineering Conference (UPEC); 2017 Aug 28-31; Heraklion, Greece. Piscataway (US): IEEE; 2017.

84. Access to electricity (\% of population). Available from: https://data.worldbank.org/indicator/EG.ELC.ACCS.ZS. Accessed 2019 Dec 4.

85. UNDP. Human Development Reports. Available from: http://hdr.undp.org/en/composite/HDI. Accessed 2019 Nov 6.

86. Malawi National Statistical Office. Fourth Integrated Household Survey (IHS4). Available from: http://www.nsomalawi.mw/index.php?option=com content\& view=article\&id=225\&Itemid=111. Accessed 2019 Nov 6 .

87. Solar energy in Malawi-List of Solar energy Companies in Malawi. Available from: http://www.malawiyp.com/category/Solar energy. Accessed 2019 Nov 6.

88. Malawi: Puma Energy. Available from: https://www.pumaenergy.com/en/ where-we-operate/africa/malawi/. Accessed 2019 Nov 6.

89. NICO Asset Managers. Monthly Economic Brief. Blantyre (Malawi): NICO Holdings Plc; 2018 Jul. Available from: https://www.nicoassetmanagers.com/ index.php/downloads/monthly-reports/98-monthly-economic-brief-july2018/file. Accessed 2019 Nov 6.

How to cite this article:

Eales A, Alsop A, Frame D, Strachan S, Galloway S. Assessing the Market for Solar PV Microgrids in Malawi. J Sustain Res. 2020;2(1):e200008. https://doi.org/10.20900/jsr20200008 